\author{
Justyna Kobus \\ Adam Mickiewicz University in Poznań \\ Institute of Polish Philology \\ ORCID: 0000-0002-4094-2743; e-mail: jusper@amu.edu.pl
}

\title{
The dynamics of changes within grammatical gender of dialectal nouns - selected issues
}

\begin{abstract}
Due to problems with obtaining the materials and the description thereof, dialectal inflection is an element of language which does not attract lots of dialectologists' attention. On the other hand, the inflection of Wielkopolska dialects poses more problems in the description because there is no starting point in the form of previous characteristics of inflection that would create a need for a continuous description that shows the changes in the evolution of a dialect. The language spoken in rural areas in the late $20^{\text {th }}$ and the early $21^{\text {st }}$ centuries has entered a stage of dynamic changes on all its levels. This fact cannot be disregarded in selecting the appropriate research tools. Dialectal inflection cannot be unambiguously categorised, it is full of inconsistencies and deviations from (what seems to be) the adopted paradigm. As a result, it is much more interesting to show it as a flexible creation of oral language i.e. in a dynamic way, resulting from statistical analyses.

The dynamics of inflection forms within grammatical gender is a part of a larger monograph dedicated to the gender-related variability of nouns and the change of gender in the course of inflection and the well-recognised opposition of masculine gender and non-masculine gender. My intention was not only to describe phenomena of grammatical gender of the nouns recorded in contemporary Wielkopolska as well as to show the changes against the material from the $1950 \mathrm{~s}-1980 \mathrm{~s}$.

The gender category defies attempts at restoring some normative order in it. Oral language is particularly susceptible to gender-related variations where the rules of correction are suspended. Oral language tends to be dynamic and this active nature determines the intensity of the specific features of the spoken variety of the Polish language - the right form is created when an act of speech appears (conformity with the general Polish norm does not count - communication prevails). Despite its specificity, the spoken variety stays within the more or less flexible language norm.

An analysis of the materials intended to illustrate the dynamics of changes within grammatical gender leads to drawing general conclusions. Dialects are a variety of the national language to which we would like to attribute many distinctive historical and even pre-historical features. However, this is a variety of language which evolves as do the other varieties of the national language. Speakers will always choose forms which suffice for an efficient act of communication. Dialects are at a stage of their development where researchers try to determine elements typical of a dialect and forget to examine their latest structure which results from the latest communication needs of speakers in rural areas.
\end{abstract}

Keywords: inflection, grammatical gender, dialect, language of villages.

Abstrakt: Dynamika zmian w obrębie rodzaju gramatycznego rzeczowników gwarowych wybrane zagadnienia. Fleksja gwarowa należy do tych elementów systemu językowego, które ze względu na trudności z pozyskaniem materiałów i sposobem ich opisu, nie jest częstym obiektem zainteresowania dialektologów. Natomiast fleksja gwar wielkopolskich jest dodatkowo trudna w opisie, 
gdyż brak tu punktu wyjścia w postaci wcześniejszej charakterystyki problemu odmiany, któryby generował potrzebę opisu kontynuującego, pokazującego zmiany na drodze ewolucji systemu gwarowego. Język mieszkańców wsi na przełomie XX i XXI w. znalazł się w fazie dynamicznych przemian na wszystkich poziomach sytemu językowego. Fakt ten nie może zostać pominięty w doborze odpowiednich narzędzi badawczych. Fleksja gwarowa wymyka się jednoznacznemu zaszeregowaniu, jest pełna niekonsekwencji i odchyleń od (wydawałoby się) przyjętego paradygmatu. Wszystko to sprawia, że znacznie bardziej interesujące jest ukazanie jej jako plastycznego tworu języka mówionego, zatem w sposób dynamiczny, uzyskany na podstawie analiz statystycznych.

Dynamika form fleksyjnych $w$ obrębie rodzaju gramatycznego to opracowanie będące częścią większej monografii, a poświęcone zagadnieniu wariantywności rodzajowej rzeczowników oraz zjawisku zmiany rodzaju podczas odmiany, a także znanej kwestii opozycji rodzaju męskoosobowego i niemęskoosobowego. Moim zamiarem było nie tylko opisanie ciekawszych zjawisk z zakresu rodzaju gramatycznego rzeczowników zaobserwowanych w języku współczesnych Wielkopolan, ale i wykazanie zmian w zestawieniu z materiałami lat 50.-80.

Kategoria rodzaju wymyka się próbom normatywnego jej uporządkowania. Szczególnie podatny na wariancje rodzajowe jest język mówiony, gdzie niejako zasady dotyczące poprawności ulegają zawieszeniu. Język mówiony ma naturę dynamiczną i ten właśnie jego aktywny charakter determinuje stopień natężenie poszczególnych cech mówionej odmiany polszczyzny - odpowiednia forma powstaje z chwilą kreowania aktu mowy (nie liczy się zgodność z normą ogólnopolską - ważna jest przede wszystkim komunikatywność). Mimo swej specyfiki odmiana mówiona mieści się w ramach mniej lub bardziej elastycznej normy języka.

Analiza materiałów, mających zilustrować dynamikę zmian w obrębie rodzaju gramatycznego, daje przesłanki do wyciągnięcia wniosków ogólnych. Gwary są tą odmianą języka narodowego, której chcielibyśmy przypisywać wiele cech dystynktywnych, historycznych, a nawet prahistorycznych. Jednakże jest to odmiana języka, która ulega ewolucji wraz z resztą odmian języka narodowego. Użytkownicy języka będą zawsze wybierać takie formy, które wystarczają dla sprawnego przeprowadzenia aktu komunikacji. Gwary znalazły się w takim momencie swojego rozwoju, w którym badacze starają się wyłuskiwać elementy typowe dla dialektu, zapominając o badaniu aktualnej ich struktury - wynikającej z bieżących potrzeb komunikacyjnych użytkowników języka wsi.

Słowa kluczowe: fleksja, rodzaj gramatyczny, gwara, język mieszkańców wsi.

\section{Introduction}

Dialects spoken in Wielkopolska are the only dialects in Poland in which no section of the language system has been examined in a complex way. For years, the system of dialects has remained at a stage of irrevocable disintegration. It is impossible to discuss a system as an arrangement of some immutable grammatical features. It would be difficult to describe the systemic features in line with model paradigms. At this stage of evolution of dialects, we can resort to a description of what is left in the language spoken in rural areas from the old, traditionally defined dialects and how old features coexist with the contemporary grammar of the (local, dialectal) oral language. Therefore it is a good idea to examine contemporary dialectal materials and whatever is left from dialectological work from the previous era as links that bind the old quality (traditionally defined dialects (gwary)) and the specific contemporary novum (referred to by dialectologists as language of villages język mieszkańców wsi).

Before I proceed with the substance, let me present briefly the condition of research into dialectal inflection. 
It has been common practice to view regional (or rather local) varieties against the general Polish language. Literature on inflection of the general language is quite impressive and the concepts very diverse, unlike works on dialectal inflection. Practically each monograph dedicated to the dialect of a specific area or village contains comments (more or less extensive) on the grammatical system. Information about inflection is also available in prefaces to dialectal dictionaries and dialectal atlases (the latter include mapped grammatical phenomena, e.g. Atlas gwar polskich (AGP) and Atlas języka $i$ kultury ludowej Wielkopolski (AJKLW)). Many works on dialects can be viewed as archival as they document the condition of dialects from their "heyday". Dialectal monographs which focus specifically on inflection include the works of the following authors: Adam Kleczkowski (Kleczkowski 1920), Janusz Siatkowski (Siatkowski 1962), Feliks Pluta (Pluta 1964), Jan Tokarski (Tokarski 1964), Hubert Górnowicz (Górnowicz 1967), Maria Grad-Mucowa (Grad-Mucowa 1970), Jan Mazur (Mazur 1978), Janina Gardzińska (Gardzińska 1989), Sergiusz Rudnicki (Rudnicki 2000), Kazimiera Pastusiak (Pastusiak 2004). More recent works are scarce, including H. Kurek's (Kurek 2019) monograph partly dedicated to language of villagers and J. Kobus' (Kobus 2019) publication entirely dedicated to the inflection of the noun in the dialects spoken in Wielkopolska.

Meanwhile, the language spoken in the late $20^{\text {th }}$ and the early $21^{\text {st }}$ centuries has been undergoing dynamic changes on all the levels of the language system. This fact cannot be ignored in selecting the research tools to analyse old and contemporary materials. It comes as no surprise that, to a large extent, phonetics are aligned with the general Polish language while the vocabulary is diverse. However, dialectal inflection cannot be classified in an unambiguous way as, just like the national Polish language, it is full of inconsistencies and deviations from (what seems to be) the adopted paradigm. As a result, it is much more interesting to show dialectal inflection in a dynamic way, drawing on statistical analyses. This issue is particularly distinct in an analysis of grammatical gender as presented in this work.

In my opinion, the language spoken in contemporary rural areas necessitates a new description that would consider the profound changes that have affected language of villagers in the past decades (cf. Kobus 2015, 123-140). As J. Sierociuk aptly noted, "The shift in the point of gravity from observations typical of traditional dialectology (a dialect) to a general view which results from idiolectal analyses, taking into account the generational differences, abstaining from the differentiation of a description in favour of a holistic approach to linguistic practices (language of villages) seems to be enforced by the latest situation in the academic circles" (Sierociuk 2007, 533).

The new methodological approach pertains to any dialectological research. An academic reflection on inflection in dialects (especially in Wielkopolska, not surveyed in this respect) should include a diagnosis of its condition in the past. This is a multistage task and its success largely depends on the multitude of material collected by dialectologists in the past. A question arises if there is such a thing as a separate inflection system (with reference to the general Polish system). There is no holistic work on the subject. We only have at our disposal monographs from the 1960s and 70s where the authors did not focus much on a broader description of declination of the nouns although some issues were discussed (mentioned) there: Monika Gruchmanowa 
(Gruchmanowa 1970), two monographs by Henryk Nowak (Nowak 1970 and 1982) and two more by Zygmunt Zagórski (Zagórski 1967 and 1991). The already mentioned AJKLW is the major work on Wielkopolska, including analyses of specific phenomena and documenting dialects from Wielkopolska, mainly in the 1970s.

This work focuses on the dynamics of changes within the gender of the noun in the language of villages spoken in Wielkopolska ${ }^{1}$.

In the Polish language, the gender category is of strategic importance; firstly, it determines the declination classes. Secondly, it has primarily syntactic functions of signalling relations between elements of a sentence.

A question arises about the number of genders in the Polish language. There are many gender-related classifications ${ }^{2}$. I have decided to adopt the most traditional division into masculine, feminine and neuter gender coupled with forms of two genders for the plural: masculine and non-masculine ${ }^{3}$. This is topped with animate and inanimate nouns which division leads to two sub-genders in masculine genders, namely

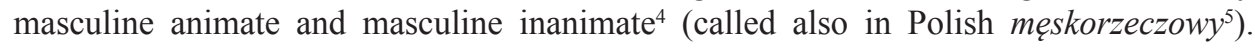
The animate/inanimate aspect is sometimes referred to as the category of cognitive relevance (see Ampel-Rudolf 2009, 209-221). A. Nagórko emphasised that "unlike in the masculine gender, the feminine category does not differentiate between the world of creatures and the world of objects. The classification of neuter nouns is even more arbitrary where this distinction is non-existent (cf. imię, ciele, dziewcze, chłopię). We should be aware of the fact that where the animate : inanimate opposition emerges, it is a linguistic rather than actual category" (Nagórko 1996, 128).

Formal determinants are also important, e.g. the end of a word stem or a specific ending. As for morphological determinants, there are hard-stem nouns and soft-stem nouns as well as vowel- and consonant-nouns. The gender-related classification

${ }^{1}$ Inflection-related phenomena in the contemporary language spoken in Wielkopolska villages (i.e. in materials obtained after 2000) with references to earlier materials (from the 1950s-80s) on the subject in question within nominal categories are included in a monograph by J. Kobus Studia nad fleksja rzeczownika $w$ gwarach wielkopolskich (Poznań 2019). The work does not have the ambition to provide a total description but rather focuses on more interesting linguistic phenomena and mechanisms in the language spoken in Wielkopolska. My intention was to show the specific dynamics of the changes rather than a static description of typical systemic features. The monograph contains detailed analyses of selected phenomena with emphasis placed on the gender, case and number.

2 See (Tokarski 1949, 8-16), (Mańczak 1956, 116-121), (Saloni 1976, 43-78), (Kucała 1978 i 1976 , 79-87), (Karpluk 1974, 87-90), (Preyzner 1986, 221-228), (Brzozowska 2005, 36-42), (Andrzejczuk 2011, 273-283), (Staszewska 1975, 101-116), (Woliński 2001, 303-305), (Wojdak 2013) et al.

3 Works on dialects provide various gender-related classifications, oftentimes based on the traditional classifications from literature on the general Polish language. However, Józef Kąś' classification is not embedded in the vast dialectal material. He has differentiated between I masculine declination, II masculine animate declination, III masculine inanimate declination, IV feminine declination, V neuter declination and VI non-masculine declination - see (Kąś 2015, 71-81).

${ }^{4}$ I. Bobrowski (Bobrowaki 2005, 83-89) has presented detailed classifications where the gender of a noun depends on its number.

5 A. Nagórko, quoting from Gramatyka współczesnego języka polskiego. Morfologia, R. Grzegorczykowa, R. Laskowski, H. Wróbel (eds.), differentiates five genders in the Polish language: masculine gender, masculine animate gender, masculine inanimate gender, feminine and neuter gender (Nagórko 1996, 95). 
adopted here seems sufficient for my analyses. Creation of a declination model for the dialects in Wielkopolska requires very large source databases and a compact area. However, the dialect spoken in Wielkopolska consists of too many diverse dialects to adopt a priori a specific, systematic paradigm.

The remaining issue are the plurale tantum nouns which occur exclusively in the plural form; academics have adopted three approaches of determining their gender; the subject was covered in detail by Teresa Friedelówna (Friedelówna 1968): 1. These nouns are non-masculine nouns (in opposition to the statement that "they do not have masculine gender because they are never accompanied by the determining words that would have the formal meaning typical of the masculine category" (Friedelówna 1968, 8 ); 2. They are classified into three major genders (repartition of the endings M. and F. plural. $)^{6}$; 3. a plurale tantum as a notion of a separate category of nouns which occur only in the plural (semantic reasons) ${ }^{7}$. In this work, I treat plurale tantum nouns as a separate category abbreviated as pl.tant.

It is primarily the syntax that determines a noun's affinity with a specific gender. Helena Grochola-Szczepanek has presented the relations between gender and syntax in a concise way: "Every noun and pronoun has a specific, invariable and syntactically independent value of this category. In the remaining parts of speech, whose syntax depends on the noun (adjectives, numerals and verbs), gender is an inflection category. (...) In the most popular syntax approach, a noun's gender is determined on the basis of its relations with the other words in a sentence" (Grochola-Szczepanek 2010, 157158). Marta Nowosad-Bakalarczyk has noted that "In multi-faceted descriptions, gender is treated as a «language category 'located and described on various' levels of language: the inflection, syntax, word-forming, as well as the context and con-situation»" (Nowosad-Bakalarczyk 2009, 7). Many times, the syntax function has made it possible to decide a difference or to indicate the gender in dialectal materials where a specific form has the expected grammatical gender (which, for example, stems from the morphology of a lexical unit).

Obviously, the above mentioned issues are not isolated from determinants of extra-linguistic nature; natural gender, while close to naïve thinking about the structure of language, can dramatically distort a precise pattern of inflection or the classification of a specific grammatical gender (where the formal determinants are of no value). These situations are common for oral language and make linguists ponder what to do with a language fact while a speaker does not see the problem. What is more, the speaker's utterance remains comprehensible.

I have limited the category of gender in dialects (in language of villagers) to a description of interesting phenomena. I am most interested in observing phenomena

${ }^{6}$ T. Friedelówna indicated a stance adopted by G.S. Bandki, F.K. Malinowski, A.A. Kryński and the grammar of L. Stein and R. Zawiliński and T. Lehr-Spławiński and R. Kubiński (Friedelówna 1968, 6-7).

7 T. Friedelówna mentioned J. Loś, S. Szober and H. Gaertner as researchers focused on the semantic issues of the pl.tant category (Friedelówna 1968, 8-9). 
(frequent in the general Polish language) which have been examined by linguists ${ }^{8}$ and may be the starting point for materials from Wielkopolska.

The gender of nouns in dialects has not been properly examined. The few works on dialectal inflection only touch upon the gender category, e.g. H. Górnowicz only characterised the masculine, feminine and neuter declinations with respect to repartition of endings (Górnowicz 1967, 150-166). Similarly, J. Tokarski listed the endings characteristic of the specific declinations for the three genders (Tokarski 1973, 91113). M. Grad-Mucowa adopted a similar approach to describing dialectal inflection (Grad-Mucowa 1970). Similarly, gender was not analysed in an in-depth way by H. Nowak who only presented the elements (endings) which deviated from the general Polish (Nowak 1970, 164-177) while Zygmunt Zagórski discussed the issue of masculine and non-masculine genders in the dialects spoken in the vicinity of Konin and commented on untypical endings in the specific declinations (Zagórski 1991, 29-38); J. Siatkowski focused on describing the three declinations (masculine, feminine and neuter), starting with a review of case-related endings by describing the differences of the form in the four basic types of the masculine declination and indicating the forms deviating from the norm (Siatkowski 1962). According to F. Pluta (Pluta 1964, 63-68) it was of importance "(...) to add some details to some isomorphs identified by K. Nitsch and to supplement inflection with new details. I discuss only the endings the use of which is different from the general Polish language" (Pluta 1964, 63). What is more, he identified the problem of changing gender as exemplified in sub-point a) together with examples in each described gender. S. Rudnicki (Rudnicki 2000) drew attention to nouns which occur in different genders; the subject has not been largely discussed and, further in the monograph, he characterised the declinations and described the alternations in the noun stem. K. Pastusiak (Pastusiak 2004) also just mentioned the gender-related fluctuations. Another noteworthy work is by Barbara Reczkowa (Reczkowa 1966, 257-261), an article entirely dedicated to gender in Polish dialects; I will return to the subject further in my work.

Due to the basically one-sided condition of descriptions of gender in dialects (including the Wielkopolska dialect), in my analyses of the language spoken in rural areas I will refer and draw conclusions on the basis of the collected dialectal material and observations of gender-related phenomena in the general Polish language (as a point of reference). I have decided to refer to works by Z. Kurzowa (Kurzowa 1970), M. Nowosad-Bakalarczyk (Nowosad-Bakalarczyk 2009), J. Reichan (Reichan 1975), Z. Saloni (Saloni 1976, 43-78), Z. Zaron (Zaron 2004a, 2004b), W. T. Stefańczyk (Stefańczyk 2007) and others. In order to understand some processes, I adopted a broader and deeper outlook on some phenomena. Here the following publications proved helpful: I. Bajerowa (Bajerowa 1977, 13-25), M. Bańko (Bańko 2012), J. Kuryłowicz (Kuryłowicz 1968), M. Kucała (Kucała 1978) and others. The bibliography at the end of the article is a full list of the reference literature.

\footnotetext{
${ }^{8}$ Encyklopedia wiedzy o języku polskim contains an entry grammatical gender in dialects where attention is drawn to masculine gender and the syncretism of masculine animate gender (although limited to the dialects of Małopolska) and within the major genders (EWJ, entry: grammatical gender in dialects).
} 
In order to describe gender in the contemporary language of villagers, I have selected continuous texts (TWsp. $)^{9}$, materials from students' recordings (MatStu. $)^{10}$ and materials obtained in educational projects ${ }^{11}$ (including replies in a questionnaire distributed among pupils and their family members as part of an educational project in

9 TWsp. are contemporary texts from the archive of the Dialectology Workshop. I have selected transcribed conversations with the informants, predominantly after 2000. These are own recordings collected during field explorations to date and the results of Prof. J. Sierociuk's research. The materials come from the following major locations: Adamów (Golina commune, Konin county) - 130 pages of transcription, Baranówko and Sowinki (Mosina commune, Poznań county - treated as a single research point due to the fact that only an administrative barrier divides the villages) - 159 pages of transcription, Bukówiec Górny (Włoszakowice commune, Leszno county) - 629 pages of transcription (original version, no BazBG), Dąbrówka Wielkopolska (Zbąszynek commune, Świebodzin county) - 214 pages of transcription. Sometimes, I refer to data from additional locations: Sienno (Wagrowiec commune and county) - 13 pages of transcription, Łowęcin (Swarzędz commune, Poznań county) - 20 pages of transcription and Krzyszczewo (Gniezno commune and county) - 40 pages of transcription.

${ }^{10}$ MatStu. are materials obtained by students as part of dialectology classes carried by Prof. J. Sierociuk. The questionnaires for the students were only partly dedicated to the inflection of the noun. In total, 57 different items in the questionnaire carried out in 2014-2017 were related to the subject: 2014 - 794 inflection confirmations, 2015 - 351 inflection confirmations, 2016 - 1269 inflection confirmations, 2017 650 inflection confirmations. In total, more than 3,400 replies related to the inflection of the noun (direct confirmations - provided as first replies, secondary confirmations - provided by an informant as the socalled second form or as a reply of another informant present during a recording, negative conformations [incl. no replies]). The research points as part of MatStu.: Biezdrowo, Wronki commune, Szamotuły county; Chocicza, Nowe Miasto n. Wartą commune, Środa Wlkp. county; Czartowo, Skulsk commune, Konin county; Dakowy Mokre, Opalenica commune, Nowy Tomyśl county; Dąbrówka Wielkopolska, Zbąszynek commune, Świebodzin county; Dębe, Żelazków commune, Kalisz county; Dobrogustowo, Obrzycko commune, Szamotuły county; Genowefa, Krzymów commune, Konin county; Gniezno, Gniezno commune, Gniezno county; Golina, Golina commune, Konin county; Gostyń, Gostyń commune, Gostyń county; Kawcze, Bojanowo commune, Rawicz county; Kępno, Kępno commune, Kępno county; Kiełczewek, Grzegorzew commune, Koło county; Koło, Koło commune, Koło county; Konary, Koło commune, Piła county; Konin, Konin commune, Konin county; Konin / Pogoń Gosławicka, Ślesin commune, Konin county; Kopanina, Damasławek commune, Wągrowiec county; Krajkowo commune, Mosina, Poznań county; Kruczyn, Środa Wlkp commune, Nowe Miasto county; Kunowo, Gostyń commune, Gostyń county; Kuny, Władysławów commune, Turek county; Kwiatków, Brudzew commune, Turek county; Leszno, Leszno commune, Leszno county; Lubasz, Lubasz commune, Czarnków county; Ludwinowo, Krobia commune, Gostyń county; Niepart, Krobia commune, Gostyń county; Niewierz, Duszniki commune, Szamotuły county; Odolanów, Odolanów commune, Ostrów Wlkp. county; Otorowo, Szamotuły commune, Szamotuły county; Pępowo, Pępowo commune, Gostyń county; Piła, Piła commune, Piła county; Pogorzela, Pogorzela commune, Gostyń county; Posadowo, Krobia commune, Gostyń county; Poznań, Poznań commune, Poznań county; Poznań Kotowo, Poznań commune, Poznań county; Przybysław, Żerków commune, Jarocin county; Przybysławice, Raszków commune, Ostrów Wlkp. county; Pyszczynek, Gniezno commune, Gniezno county; Rawicz, Rawicz commune, Rawicz county; Rokietnica, Rokietnica commune, Poznań county; Rychwał, Rychwał commune, Konin county; Ryczywół, Oborniki commune, Oborniki county; Słomczyce, Strzałkowo commune, Słupca county; Szczurowice, Raszków commune, Ostrów Wlkp. county; Śrem, Śrem commune, Poznań county; Święciechowa, Święciechowa commune, Leszno county; Tarnówka Wiesiołowska, Dąbie commune, Koło county; Witaszyce, Jarocin commune, Jarocin county; Zduny, Zduny commune, Leszno county.

11 The materials from the two educational projects come from research locations in Gniezno county: Modliszewo, Modliszewko, Strzyżewo Kościelne, Goślinowo, Łabiszynek, Szczytniki Duchowne, Lubochnia, Wola Skorzęcka, Mnichowo, Gniezno and in Czerniejewo county: Brzózki, Goraniec, Graby, Nidom, Pakszyn, Nidom, Graby, Goraniec, Czerniejewo. 
Modliszewko (Gniezno county and commune) ${ }^{12}$. Materials from questionnaires for the AJKLW serve as background material (and sometimes the starting point), further referred to as the KwAJKLW ${ }^{13}$ and for the TGPnW ${ }^{14}$.

In the 1950s and 70s, the informants were selected from the locals who had lived in their villages for generations. As long as it was possible, illiterate locals were selected or ones with only a few classes of the village school. Preferably, a potential informant did not leave his/her village during his/her lifetime ${ }^{15}$. For this reason the individuals from whom the material was obtained came from: the TGPnW in 18661901, the KwAJKLW - in 1879-1926.

The selection of informants in contemporary materials was slightly different. The quoted informants come from both rural and urban areas (influx from cities). Most of them come from Wielkopolska. There are also individuals from other regions although at the time of the exploration they had been settled in their respective villages.

They also represented different education levels. The group includes people with only primary education (including German schools), graduates of secondary and tertiary schools, people professionally involved in farming or commuting to work in the city; there are also individuals running businesses other than farming on site and people handling two professions (running farms and working in the city). The contemporary informants were born in the following time: the TWsp. - 1910-1972, MatStu. in 1921-1970 and educational projects - 1922-1982.

Clearly, the age differences of the informants are quite big and require ordering. By accepting J. Sierociuk's solution I have arranged the informants by the year of birth in the following generation groups: I. born before 1920, II. born in 1921-1945, III. born in 1946-1970, IV. born in 1971-1995, V. born in 1996 and later (Sierociuk 2003, 133). Therefore, the inflection materials represent generations I and partly II (archived materials) and the generational brackets I-IV (contemporary materials).

\footnotetext{
12 A questionnaire distributed in Modliszewko (Gniezno commune and county) was a part of the educational project Holidays, beliefs and superstitions - the language and traditions of villages in Gniezno commune. The questionnaire revolved around 23 issues aimed at determining the level of linguistic awareness and the respondents' identification with the local language as declared) and at confronting the declarations with the actual command of dialects/knowledge of dialects (questions about specific names, the meaning thereof, variants etc.). The results have been presented in an article (Kobus, Gniazdowski 2017, 156-157).

${ }^{13}$ KwAJKLW represents unpublished materials in questionnaires for the AJKLW (the 1970s). The issues related to the inflection of the noun include 646-802; two of them refer to pronoun (Q 682 swojóm and 683 mojóm). Therefore we need to refer to the materials obtained from the replies to 154 questions in the KwAJKLW in 111 questionnaire books (Sobierajski 1972a, 1972b, 1972c).

${ }^{14}$ (TGPnW) - dialectal material obtained in 1953. The book has 224 pages; the presented dialectal texts come from 11 villages and are printed on 212 pages; the texts were fed into Microsoft Excel and Microsoft Access, they represent 59,169 records. In my descriptions of the remaining categories I also used the (TGŚrW) and (TGZchW) materials.

${ }^{15}$ K. Nitsch (Małecki, Nitsch 1934, 18-19) expressed his opinion on the selection of informants for dialectological research; in 1979 Z. Sobierajski (AJKLW-I, parts 2, 14) characterised an informant in reference to the Poznań survey in the 1950s-80s.
} 


\section{The variations of the type of nouns in Wielkopolska dialectal materials}

Gender variability, gender variation, gender alternatives, gender alternations, double gender, the syncretism of genders, shared gender nouns, gender doubles, multi-gender - these and many other phrases have been used to refer to the occurrence of the same words / names in more than one gender. Of importance here is the differentiation of the specific concepts (which cannot be treated as synonymous) and the perspective of chronology and geography.

Let me process with a review of the literature and an analysis of the material and with defining the scope of the issue at hand. Firstly, in my analyses I will use the concepts of a variant, variability and multi-gender interchangeably as the diversity of genders. I believe that for variability to take place, a noun must at least occur in two different genders in the speech of a single language user, the inhabitants of a single dialectal area or in the speech of language users from the area of a single dialect or even a dialect. The gender variability may pertain to the geography, declinations and time. Depending on which point of the analysis we adopt as the starting point (i.e. what we can prove), there is also variability in the dialects from the 1950s and now, there is also variability in a special time - all these issues relate to a compact language area. In a discussion on variability, references to the general variety of the Polish language can be of assistance; a word from language of villagers which occurs in a specific village other than in general Polish, against a specific dialect is not a trace of numerous genders. It is only when juxtaposed with a normative gender that the audience finds out that a dialectal form is a variant in relation to an invariant ${ }^{16}$ existing in the general Polish language. Since the theory of variability pertains to certain layers in the language system, going down the layer i.e. to varieties of the Polish language, we will define variants within dialects (i.e. outside the general language). In a broadly defined dialect, one can also define variants for an existing invariant (remembering not to refer to all the names in the various grammatical genders from all the dialects and dialects as variability - that would lead to an erroneous conclusion about unlimited variability in Polish dialects; rather, I mean local analyses, most broadly limited to a single dialect). By gradating the language structure, starting with the general Polish language, through regional, dialectal and family language, we reach the lowest idiolectal level; here also an invariant with its variants can be identified.

Speaking about variability, it is impossible to disregard double gender. Roman Laskowski has characterised this group of nouns in the following way: "(...) two-gender nouns enjoy a specific status as part of the gender category, like SIEROTA, KALEKA, NIEZDARA, DZIENNIKARZYNA, with a personal, oftentimes pejorative meaning, with an ending -a in the nominative singular. These nouns assume the feminine or masculine animate grammatical gender: N. singular ta / ten sierota, G. singular tego / tej sieroty etc. but Nominative = Accusative plural always te sieroty" (Laskowski

${ }^{16}$ See Adam Heinz's theory (Heinz 1974a, 137-157). A. Heinz wrote: "The differentiation of invariants and variants in language is among the major achievements of structuralism in linguistics although in fact it is not something very new bearing in mind that this is nothing else but differentiating between important (fixed) features and occasional (variable) features which are inherent of any existence and any phenomenon in general" (Heinz 1974a, 138). 
1998, 213). Zdzisława Staszewska refers to this group of nouns as nouns with shared gender (Staszewska 1975, 102-103) ${ }^{17}$. The issue was examined by Z. Zaron who highlighted not only the gender-related alternations in the plural but also syntactic and semantic issues in this specific class of nouns. Ultimately, the researcher concluded that "(...) the «two-gender» label has been used with respect to noun-related personal names (ending with an $-a$ in Nominative singular) with alternative syntactic and semantic possibilities. However, with this approach to double gender, this class should be extended by two subclasses with similar syntactic characteristics although with a different ending in the nominative case singular. The first sub-class is represented by nonbased names of individuals, derived by means of the modifying augmentative -depreciative formant -ysko / -isko, -ajło, -dło, the type To / ten chłopaczysko..., To / ta dziewczynisko... Ten / ta / to strachajło. (...) The other subclass of nouns is represented by names of people due to their functions and professions, the type Przyszedt doktor Kowalski. / Przyszła doktor Kowalska or Pan radca mówił / Pani radca mówiła, że zaraz skończy" (Zaron 2004b, 167-168).

B. Reczkowa had an entirely different outlook on double gender. She described her research into double gender of nouns in Polish dialects in the aforementioned article (Reczkowa 1966, 257-261). She attributed the phenomenon of double gender in the category of arbitrary nouns to "(...) the intertwining influences of various arbitrary nouns on derivative nouns, on the level of shared semantic functions of arbitrary and derivative nouns" (Reczkowa 1966, 261). What is more, B. Reczkowa quoted J. Kuryłowicz who acknowledged a plethora of gender alternatives in dialects. She also adopted Kazimierz Nitsch's view of the geographic diversity of gender (at least some words) which phenomenon divides Poland into northern and southern (Reczkowa 1966, 258). Therefore, in Wielkopolska it should be: ta cień, ta dyszel, ta grzadziel, ta lemiesz. The scholar checked the extent to which this state results from historical and linguistic processes. It would be interesting to see if and to what extent, in B. Reczkowa's theory, double gender of nouns exists in Wielkopolska.

In my analyses, I do not use the term double gender but variability (or multi-gender). Variability is a concept broader than double gender as interpreted by B. Reczkowa and does not limit itself to a specific number of variants; neither does it limit a specific group of nouns solely to a group of individuals as Z. Zaron sees it. The very name double gender as interpreted by the two researchers is exclusive and relates to an entirely different group of nouns. In the case of specific material like language of villagers, gender variability is more adequate (or multi-gender). This concept takes into account double gender of the two mentioned concepts. Results of the analyses will show to what extent the phenomenon exists in Wielkopolska.

Another notion calls for comment, the mentioned multi-gender. Piotr Wojdak has described it in the following way: "Multi-gender occurs whenever there is a set of morphologically related noun forms (in a special case, unaltered forms alone) with identical lexical meaning which cannot be broken down to a single standard noun as a mono-gender lexeme while nouns with different genders cannot be separated without the shared part («knot») in the form of indistinguishable forms. (...) One could say

\footnotetext{
17 The scholar adopted the phrase from Danuta Buttler (Buttler, Kurkowska, Satkiewicz 1973, 134).
} 
that multi-gender (double gender / triple gender) is a relation constituted by (two / three) various noun lexemes «of some sort», namely semantic doubles, grammatically «conjoined» despite the gender difference" (Wojdak 2013, 73). To me, this term is synonymous with variability.

Another important publication is a book by T. Skubalanka and W. Książek-Bryłowa (Skubalanka, Książek-Bryłowa 1992, 22) with references to research into dialectal inflection.

When explaining the inadequacy of the terms double, alternative form, inflection synonym, Teresa Skubalanka justified her choice of terms variant and variability (not variance $^{18}$ which she rejected for euphonic reasons) (Skubalanka, Książek-Bryłowa $1992,22)$. In her presentation of works dedicated to inflection variability, T. Skubalanka regarded A. Heinz's theory as key to the examination and description of dialectal inflection. Heinz referred to the process of variability as “(...) multiplication of a specific system unit" (Heinz 1974a, 139). The scholar saw the crux of variability entangled in stylistics and/or text. The mechanism of variability boils down to several changes: "1. Forms against the same function (semantic or syntactic), e.g. the inflection forms of an adjective different with respect to the form but of an identical functions. 2. The function (semantic or syntactic) against the same form, e.g. the function of an object and an adverbial in the accusative case. 3. The form and function of secondary importance to the primary form and function, e.g. oblique cases of a noun and a noun as such" (Heinz 1974a, 140). Of importance is also his statement related to the variant and its invariant: “(...) in fact there are only variants while their classes are based on a group of identical features i.e. invariant and relevant at the same time, they create abstract system units" (Heinz 1974a, 140).

When analysing Heinz's concept, Skubalanka made her point: "As for the details, i.e. inflection variants, according to Heinz inflection categories are formal and functional textual variants in the parts of speech category. On the other hand, each inflection form is subjected to textual variability (taking place on the line of text); as a result, the inflection categories are a part of the system and of the text. Inflection is nothing else but «a textual variant» adjusted to the specificity of system units i.e. parts of speech" (Skubalanka, Książek-Bryłowa 1992, 15).

By referring to A. Heinz's theory and the vast literature on the subject, the scholar presented her own definition of a variant which I consider closest to my train of thoughts". Inflection variants are:

1. Identical or close with respect to the function (in the same paradigmatic position, e.g. case, person) but different with respect to the morpheme composition (a case in point being the normative alternative forms in $\mathrm{N}$. plural of masculine nouns with different semantic shades of sub-category nature, i.e. panowie, chlopi, the expressive chłopy, snopy, konie) or different with respect to another aspect of usus (cf. the normative neuter chłopi, expressive chłopy against the colloquial neuter and dialectal form chtopy; the colloquial neuter chtopi against the colloquial neuter chłopy etc. - there are many possible variant arrangements);

18 Variance was researched by M. Brzezina (Brzezina 1982); while she did not devote much attention to dialects, the method and way of describing variance seems interesting. 
2. Identical in the composition but different in the function as part of a more general category excluding regular homeomorphism, e.g. the infantile robitem in feminine gender form against the normative robiłem in masculine gender, the impersonal form napisano, wydobyto as impersonal forms in the official language use etc." (Skubalanka, Książek-Bryłowa 1992, 32). Next, T. Skubalanka defined the area of observation of variants which she does not view against a system but a text and, consequently, she can characterise usus in a specific set.

In describing the gender-related variability in dialects, Mieczysław Karaś's stance is of interest. In his approach to the diversity of genders in dialects, he concluded: "[unlike in the plural masculine and non-masculine gender - JK] the main genders: masculine, feminine and neuter, are far less diverse. The differences like klusek - klus$k a$, skwarek - skwarka, kłębek - kłębko, typical of various words, are not numerous. Fluctuations in nouns ending with (contemporarily or historically) soft consonants are more common: biel, cień, darń, dyszel, gardziel, grzadziel, jedwab, jesień, krtań, lemiesz, obręcz, poręcz, rdzeń, sążeń, żoładź and are either masculine or feminine. In the south, ten cień, ten dyszel, ten grzadziel, ten lemiesz prevails while in the north it is ta cień, ta dyszel, ta grzadziel, ta lemiesz (...)" (see the EWJ, entry: grammatical gender in dialects). The analyses below will show if the presented research results are confirmed in the language spoken in Wielkopolska in the past and now, at least with respect to some examples mentioned by M. Karaś.

The origin of variants was presented in detail by S. Urbańczyk (Urbańczyk 1977, 75-83). He selected types of variants according to opposite features: old - new, living - dead (obsolete), general - regional, regional A - regional B (e.g. spoken in Warsaw - Krakow), familiar - borrowed, written - oral, literary (standard) - dialectal (sub-standard) (Urbańczyk 1977, 76-79). With reference to the oppositions mentioned by S. Urbańczyk, my analyses will revolve around the relations between old - new (formerly - now), general - regional (dialectal), written - oral and literary (standard) - dialectal (sub-standard). I will only briefly mention the obsolete relation (living - dead) in a situation when old material is discussed and/or forms not occurring today plus the spoken component (from the written - oral opposition). This holds true for all of the material (the recorded dialectal texts, while expressed in writing, are only a graphic reflection of the spoken code). The remaining juxtapositions: regional $\mathrm{A}$ - regional $\mathrm{B}$ (e.g. Warsaw - Krakow), familiar - borrowed, will appear sporadically (in single examples).

Let me start with a review of the material from Wielkopolska included in older sources: the TGPnW and the KwAJKLW, and cotemporary ones.

Before I proceed with an analysis of specific examples, I will provide the statistical characteristics of the set of dialectal texts with respect to the content of gender forms. 
Table 1.1. The statistical characteristics of the TGPnW

\begin{tabular}{|c|c|c|c|c|c|}
\hline $\begin{array}{c}\text { all records } \\
\text { (= word forms) }\end{array}$ & all nouns & $\begin{array}{c}\text { all nouns } \\
(\%)\end{array}$ & $\begin{array}{c}\text { nouns in line with the } \\
\text { general Polish norm }\end{array}$ & $\begin{array}{c}\text { nouns not in line with } \\
\text { the general Polish norm }\end{array}$ \\
\hline 59169 & 10396 & $17.57 \%$ & $99.57 \%$ of all the nouns & $0.42 \%$ of all the nouns \\
\hline \multicolumn{5}{|c|}{} \\
\hline $\begin{array}{c}\text { numeral representation } \\
\text { of genders }\end{array}$ & masculine & feminine & neuter & $\begin{array}{c}\text { plurale } \\
\text { tantum }\end{array}$ & unspecified gender \\
\cline { 2 - 7 } & 4801 & 3866 & 1421 & 189 & 119 \\
\hline 10,396 nouns $=100 \%$ & $46.18 \%$ & $37.18 \%$ & $13.67 \%$ & $1.81 \%$ & $1.14 \%$ \\
\hline
\end{tabular}

As the table shows, in the analysed volume of Ddialectal texts..., nouns of the masculine gender prevail, followed by nouns of the feminine gender; neuter nouns are less frequent while nouns in the plurale tantum category are among the rarest. In more than 100 uses, it was impossible to determine the gender due to lack of the context this pertained to nouns which, theoretically, can occur in different genders (and even numbers), e.g. ten dyszel / ta dyszel, ten cep / ta cepa / te cepy, ten szufel / ta szufel. This small percentage of words could represent interesting material for analysis but, due to not confirmed cases of multi-gender in these recordings, I must disregard them. Instead, I will focus on the examples which occur in the TGPnW in various genders.

In the analysed volume, I have found 120 nouns which differ from the general Polish norm with respect to the gender (the examples are repetitive) and 88 confirmations of gender variability. The number contains both nouns with a gender other than in the general Polish language and ones with different genders within a dialect (masculine, feminine or neuter); there are also examples that will serve to describe the issue of failing to recognise masculine and non-masculine in the plural form. I present this issue below; now let me choose from the excerpted examples only the ones representing multi-gender. An analysis of these examples will show if the speech of the informants examined by Z. Sobierajski in the 1950 s represents gender-related variability.

The most frequent example in the TGPnW is dyszla 'an element of a horse-drawn cart' (26 recordings) in feminine gender. Normative sources provide dyszel - masculine gender ${ }^{19}$. This referent has been described in the AJKLW-V, m. 439. According to atlas data, in Wielkopolska two genders (masculine and feminine) co-exist for the word; feminine gender prevails in the northern and north-western outskirts of the region and the Kalisz area in the south. The comments say: "The map depicts the grammatical gender of the word dyszel: masculine or feminine. Unfortunately, this grammatical category was not represented in all the locations. The masculine grammatical gender, in accordance with the general Polish norm, prevails. The feminine gender

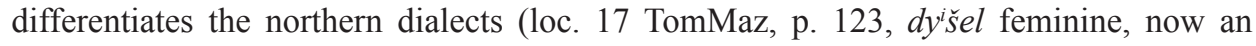

19 See for example the SJP PWN <https://sjp.pwn.pl/szukaj/dyszel.html (accessed on 15.10.2018)>, SDor, SJPSzymczaka, the NSJP and others. 
ethnographer recorded ten $d y^{i} \check{s}^{2}$ l) and a large part of the dialects in southern Wielkopolska"20.

The German etymology of the word dyszel is of importance, too. The Polish word dyszel is a borrowing from the German Deichsel 'dyszel/drawbar' which is feminine in German. Maria Karpluk has stated unambiguously that “(...) the oscillation between ten and ta dyszel results from the Polish language taking over the original, feminine gender of the borrowing and the pressure exerted by the co-existing synonym grzadziel. This synonym did not pertain to the main meaning of 'a cart draw-bar' which, to some extent, weakens the arguments here. On the other hand, in a 'draw-bar of a plough' the mutual influence of the words dyszel and grzadziel resulted in a standardised gender for these words in Polish dialects" (Karpluk 1974, 90). The fact that the feminine forms were more frequent in Wielkopolska dialects in the western and northern outskirts of the region corroborated the theory about the German influence on the gender. There are few conformations of the form ta dyszla in contemporary language of villag$\mathrm{ers}^{21}$; typically, these are examples in masculine gender as below:

\section{Adamów:}

$\mathrm{KaP}^{22}$ : nie ... sie różnił tym że konie ciongty ... no tam byt dyszel ... byt bark ... byt te ... te ... te ... a do ciongnika to przystosowany do ciongnika to już ... to już zaczep byt do ciongnienia (?) tego ...

\section{Baranówko:}

MiZ: bo jak by byt tylko dyszel to on by sie złamat wie $e^{n}$ miaty zmocnienia (!) od jednego do drugiego druty takie $i$ to byty tak na ... takie nawet śruby byty że sie przykre $^{n}$ cato że one byty na sztywno i na końcu ... na końcu tygo dyszla byt ... byt hak ... i tam sie zaktadało konie ...

\section{Bukówiec G.:}

WoS: to jez dyszel tutyj ... nie ... tutyj dalej ... nie ... a tu doton d chyba ... tu chyba sie $i$ nazywaty śnice ... nie ...

MaM: dyszel ... to byt dyszel a tuty byt taki uchwyt do tego dyszlu ... bo to nieraz zaś szło wyciongnon ć tyn dyszel do innygo wozu sie przekłodało ... ale jak to sie nazywało ...

\section{Dąbrówka Wlkp.:}

WiW: jedyn pojeżdzól koniami a drugi z tylu tyn dyszel trzymat najczy ${ }^{n}$ ści ... to dwie osoby ... co pamientóm ...

SeZ: to dwa konie ciongty ... dwa koła byty ... nie ... bo na dyszlu trzymaty ...

${ }^{20}$ (AJKLW-V, part 2, 34).

${ }^{21}$ Sporadic conformations from Bukówiec G. for the form in feminine gender ta dyszel: SzJ: tutyj przeszła dyszel do przodu ... tera na te dyszel przyszly jeszcze te ... te ... Czesio by dobrze wiedziol jak to sie nazywo to ...

${ }^{22}$ The Dialectology Workshop of the UAM has adopted a rule of publishing exclusively abbreviations denoting specific informants (other data like the year of birth or sex, presented in situations when they may be of importance to the interpretation of the text). 
Back to gender variability: the available materials suggest that the phenomenon can be viewed with reference not only to the dialectal layer (or dialectal in the synchronic aspect) but also against the general langue - dialect opposition. Of equal interest is the fact that this variability refers also to the relations between a dialect and language of villagers (two layers: formal and tempora ${ }^{23}$ ). My informants use predominantly ten dyszel which is in line with the general Polish norm; more rarely ta dyszlalta dyszel.

Another group of examples, quite large for this research sample, includes płóz (6 recordings). In the TGPnW, the word means 'an element of a plough' and is provided exclusively in masculine gender. In the AJKLW (m. 238 'A part of a wheeled plough: c. Plough hitch') the analysed name is recorded in both forms: płóz and ptoza. Notably, the feminine form was then confirmed very rarely, only in five dispersed research locations: "In locations 55, 97 and 99 [55. Dobrów, Kościelec commune, Konin county, 97. Galewice, Galewice commune, Kalisz county, 99. Świba, Kępno commune, Kalisz county $-\mathrm{JK}]^{24}$ the word proza was recorded in the meaning in question; in locations 29 and 43 [29. Szarcz-Stołuń, Pszczew commune, Gorzów county, 43. Wąsowo, Kuślin commune, Poznań county - JK] poza (płoza)" (AJKLW-III, parts 2, 18). The masculine form was definitely more frequent and it occurs in the entire dialectal area: "The type płóz is the most common name of the referent in question recorded all over Wielkopolska with an exception of the northern locations where Wielkopolska and Pomerania converge, locations in western and southern Wielkopolska" (AJKLW-III, parts 2, 17). General dictionaries of the Polish language provide predominantly the form płóz for this specific meaning but also płoza as 'a part of a sleigh/a runner' ${ }^{25}$. I mention it for a reason: the contemporary speakers of language of villagers use increasingly often the feminine form płoza when referring to 'an element of a plough'. The change in the gender is not fixed but in the process as exemplified by informants from various parts of the region (see especially an example from Sowinki: informant RaA could not indicate the gender). I recorded variability with this specific informant (see Baranówko, MiZ). Some informants have retained the masculine form płóz for a plough, e.g. Łowęcin - KaB, Bukówiec G. - SaZ but these are single cases. Parallel to it is ta ptoza 'a part of a plough'; the informants tend to use the feminine form when referring to elements of tools and vehicles reminiscent of sleighs (in line with a trend in the general Polish language), e.g. Sowinki - RaA and Bukówiec G. - WoS, SzJ (although sometimes the gender changes here, too - see the example with smyk provided by informant MiZ - Baranówko):

${ }^{23}$ I covered the vast area of temporality in many articles and the mentioned monograph (Kobus 2015a). As for the articles, the examples include (Kobus 2007a, 73-82), (Kobus 2007b, 301-305), (Kobus 2007c, 307-314) and others.

${ }^{24}$ The administrative data of the research locations as in the AJKLW, according to the then administrative division.

${ }^{25} \mathrm{https} / / /$ sjp.pwn.pl/szukaj/p\%C5\%82\%C3\%B3issuehtml (accessed on 15.10.2018)>, SDor and Szymczak's SJP. The NSJP disregards płóz and only accounts for płoza 'one of long strips placed in the front and bent upwards along which a vehicle (e.g. a sleigh) moves on the snow or ice'. 
Baranówko, MiZ - informant born in 1926

What are the parts of a plough?

MiZ: ptug ... odktadnia ... lemiesz to jest to co ... co co kroi tom zimie ... nie ... i późnij druga czy śśc to jest ta odkładnia i trzecia to jest ptoza tak zwana która prowadzi ... idzie do tylu taka lasza która tóm równowage takom utrzymuje tak ...

\section{People say that a smyk needs to be built. What is that smyk?}

MiZ: smyk to jest ... szkoda ... bo bym zaraz pani pokazat ... bo niedawno zbiłem ... (...) to takie dwa ptozy ... takie dwie beleczki na tym deski i na tym było można jechać ... nie potrzeba było do woza tylko o ... do ... do tego i tam włożyło nieraz pług $i$... i smykim jechato sie na pole ...

Sowinki, RaA - informant born in 1931

What is a smyk?

RaA: no smyk ... smyk to takie dwie ... dwie plozy so ${ }^{m} i$ w poprzyk so ${ }^{m}$ deski poprzybijane ... no coś ... czy obornik wywieź ... czy ... czy ... czy coś przywieź na tym ... nie ...

\section{It does not have wheels?}

RaA: bez kótek ... to takie płozy so $\boldsymbol{m}^{\boldsymbol{m}}$ tylko ... dwa ... dwoje plozów i na to deski sie poprzybija ... nie ... tam czy metrowe dtugi czy pótora metra dtugi ... jaki tam kto chce ... i przywiezie tam se na tym ...

Łowęcin, KaB - informant born in 1926

What is a (plough) grządziel?

KaB: grzondziel ... odktadnia ... topata mówili dawni a to jest ... lemiesz ... płóz ... pie $^{n}$ ta mówiom chyba ... płóz co po ziemi z tyłu idzie ... to płóz ... no i jag re czny ... renczny ... no to ro ${ }^{n}$ czki jeszcze ... do trzymania ...

Bukówiec G., WoS - informant born in 1959, SaZ - informant born in 1948 r., SzJ - informant born in 1925:

It is attached to the handle (of a plough)?

WoS: no ... no ... no ... to jez (?) na dole ... to jes taka płoza niby ... to na tym sie tam trzymo później ... nie ... ten ... te głembokoś sie utrzymywało ... nie ...

\section{What is a smyk?}

WoS: a smyk ... smyk ... a ... a gdzie ma pani ten drugi spód ... tu ... smyk to ... smyk to już jes coź innygo było ... nie ... to byly dwie płozy tyż ... nie ... i tu sie byto do cion $^{n}$ nnie $^{n}$ cia ... tu byty takie troche podwinie ${ }^{n}$ te ... i to właśnie $w$ ksztatcie takim byto ... nie ... i to cion $^{n}$ not koń ...

SaZ: tu but tyn wywrotek ... tu buła ... i tu buty sochy ... nie ... i ty jeszcze taki płóz ... ni móm już wywrotka bo zawiozem na złom ...

The part of a sleigh which touches the snow.

SzJ: to sóm ${ }^{m}$... no ... tag jak koła ma ... 


\section{What do you call it?}

SzJ: to jes trudno odpowiedzieć ...

What about klecka, płozy ...

SzJ: o ... plozy ... to pry ${ }^{n} d z y$... tak ...

Do you use the word ławina here?

SzJ: to nie syszatum ... plozy tak ...

One of them is a ploza?

SzJ: jedna to płoza ...

Dąbrówka Wlkp., GoS - informant born in 1939:

GoS: $a$... a ... tu z tytu jez regulacja $a$... a te ... tu jes ptoza ... nie ... ptoza ... na dole ... a ... a tutaj jes ... no te ... to tak ... akurat teraz zapomniatem jak to sie nazywa ... to jes ta $c z y^{n} \dot{s}$... no można powiedzieć czy źz robocza ... można tyż tag nazwać ... nie ... no bo to ...

The variability of the word płóz/płoza clearly indicates the dynamics of the language spoken now in rural areas. However, this is not a result solely of the processes related to grammar. By changing the gender in the indicated scope, the informants attribute the same gender to two completely different elements of completely different objects; gender ceases to differentiate these referents. Therefore, this is an example of the mutual relations between grammar and semantics.

Another example in the TGPnW which indicates a variant of the gender is murtat m. (5) 'a wooden beam placed on top of a building's wall on which the rafter framing is based ${ }^{26}$. The word was mentioned in the analysed volume only in the masculine gender. Meanwhile, the normative sources of the general Polish language the variant of the gender is in this case marked by references to the alternative form, e.g. murtata vs. murłat. In the latest dialectal materials, there is no confirmation of the example murtat/ murtata.

An interesting example is the word for 'a part of a wooden wheel consisting of a piece of the perimeter and two spokes' which in the TGPnW is mentioned in three genders: masculine ten złón/zwón (4), feminine ta zwóna (4), neuter to złóno (2). Clearly, the frequency of recording of the masculine and feminine forms is comparable; only the neuter form was recorded once. As for references to the general language, there is both to dzwono and ten dzwon in the specific meaning ${ }^{27}$. The word is not described in the KwAJKLW; contemporary materials mention it in two research locations (Baranówko and Bukówiec G.), in total 24 times in three different ways. The confirmations come from informants from two generational brackets: Baranówko: gen. II. - MiZ informant born in 1926, gen. III. - MiJ informant born in 1964; Bukówiec G.: gen. II. - MaF informant born in 1922, SzJ informant born in 1925, ŚlE

\footnotetext{
${ }^{26}$ Murłat vs. murlata: <https://sjp.pwn.pl/szukaj/mur\%C5\%82avol.html (accessed on 15.10.2018)>, SDor, SJP Szymczaka, no entry in the NSJP.

${ }^{27} d$ zwon 'an element of various devices of that shape': <https://sjp.pwn.pl/szukaj/dzwono.html (accessed on 15.10.2018)>; dzwono n. SDor 'a part of a wooden perimeter of a cart's wheel, fixed on two spokes', SJP Szymczaka dzwono n. 'a part of a wooden perimeter of a cart's wheel', NSJP - no entry.
} 
informant born in 1929, ŚlZ informant born in 1934, gen. III. - MaH informant born in 1955. The confirmations from Baranówko indicate exclusively the plural form $d z-$ wona so it is impossible to establish the basic form and its gender. On the other hand, the names confirmed in Bukówiec G. indicated distinct dynamics indicating the related changes taking place. In the field, the plural and singular forms of $d z w o ́ n o$ in the neuter form in masculine gender $d z w o ́ n / d z w o n$. Interestingly, this variability comes from informants from the same generational bracket:

SzJ: musiol te dzwóna tam wyción ć ..., tam było dzwóno ..., tam buło (!) dzwóno ..., dzwóno to buła czy śś ta ..., tam byto tylko na sześ czy osiem ... tych dzwón osiem zdaje sie ... osiem tych dzwónów byto ..., to wtaśnie mówie ... dzwóna to so ${ }^{m}$ te wkoło ..., czy $y^{n}$ 'ci ... koto to jes ... to so ${ }^{m}$ dzwona ...

ŚlE: tu jes ... tu jes ten caly dzwón ..., ŚlE: tak ... to jez dzwón ..., to ... to by dzie dzwón ... a to ... śprychy nie ...

ŚlZ: ty a dzwon co? ... dzwóny co byty? ... koło miało dzwony ..., a ja myślałam ze ... a dzwón to be dzie to wszysko z tym (...?) ...

As the described referent and name have long since been obsolete (they only exist as part of reconstruction of a wooden wheel) hence the ambiguity in using the word for 'a part of a wooden wheel consisting of a piece of the perimeter and two spokes'. Of interest is the fact that in comparison with the materials from the 1950s (and unlike them), the word in neuter gender seems to prevail although this may be attributed to the dialect.

Another example is szufel feminine (4). In the TGPnW there is no trace of a variant other than the recorded form in the feminine gender. The variant-free form $t a$ szufla is an equivalent of the general Polish word. However, in the AJKLW (m. 286 'A wooden tool for cleaning manually grains in the wind') dialectologists observed the coexistence of the word szufel in a masculine and feminine form next to the ta szufla type, in line with the general Polish language: "The names of the szufel type (f.) occur in the central and eastern parts, next to the szufla type from the north of Wielkopolska. The szufla type is characteristic mainly of southern and western Wielkopolska. It is common to the north of the Notec river; to the south of the Noteć it coexists with szufel" (AJKLW-III, part 2, 71-72).

As for contemporary research, the word has been observed by means of a student questionnaire. The word was provided as synonymous with sipy (questionnaire question: 'Sipa means...' as a referent to 'a wooden spade to shovel grains). In the obtained material, ta szufla appeared 8 times, the form taka szufel was recorded only once. Nevertheless, the noun has a feminine gender which seems to prevail. Therefore, the variability pertains not to the gender bur rather the form within the gender.

Another example is pónit/pónita 'heddles in looms, ladders made of string or thread, through which warp is passed'. The dictionaries of the Polish language do not provide an entry pónita/pónit (in other dialects also ponita) but its equivalent nicielni$c a$ (f.). Therefore, the information from the TGPnW with the general language is not analysed in this case. On the other hand, the dialectal material seems interesting where the masculine form prevails with definitely fewer representatives of feminine gender in 
a proportion 15:3 (in 5 examples, the gender could not be identified because the examples were recorded in the plural in a context not indicating the gender in the singular). The structure of looms is not described in the AJKLW; similarly, there are no proper references from the contemporary language of villagers.

Cepa f. (2) - in total in the TGPnW cep/-a/-y/-yj/-ami etc. is mentioned 26 times but only two examples have a clear gender (ta cepa - f.) and in the following 24 cases the gender is unspecified due to the plural number of the examples without a proper context. In Wielkopolska, the words for 'a wooden device to thresh grains' may come in singular as masculine or feminine as well as plurale tantum (Zierhoffer 1956, 11-23). As it is impossible to acknowledge masculine gender and the actual number of conformations in feminine gender, I need to resort to a modest research sample to continue the analyses. Finally, the SJP PWN (the online version) provides the form cepy 'a device to thresh grains' while earlier lexicographic works (the SDor, USJP, PSWP, SJPSzymczaka, NSJP) ${ }^{28}$ provided the form cep in the same meaning (typically next to the form cepy). As for contemporary field material, what attracts attention is high gender variability of the word in question within a dialect - I discussed the change in the vocabulary related to flails in a separate article (Kobus 2010, 139-146). There, I described the linguistic reality in selected research locations; I referred there to earlier research, quoting from Karol Zierhoffer who carried out in-depth studies on the subject in the 1950s and followed A. Tomaszewski's materials (disregarded here for reasons presented in the introduction): "K. Zierhoffer concluded that the materials provided by A. Tomaszewski suggest that «The name of the tool in question is not diversified in the dialects spoken in Wielkopolska. It is indicated by the word cepy $(\text { cepy, серy })^{\prime}(\ldots) »$ (Zierhoffer 1956, 12); he recorded the form cepa (Śrem county) only twice and cep in 15 villages (Czarnków, Szamotuły, Gniezno, Mogilno, Krotoszyn counties). K. Zierhoffer added: "Unfortunately, Tomaszewski did not ask much about the Nominative of the singular and the Genitive of the plural so his data on the issue included in various materials are sporadic and accidental»»" (Zierhoffer 1956, 11-23 $)^{29}$. As for an analysis of the AJKLW, the authors reached the following conclusions: "The comments to the AJKLW-III read: "The differences in the names pertain to the number and the gender of the word cep. In Wielkopolska, the word is diverse predominantly with respect to the singular and plural. Oftentimes, both forms occur optionally» (the AJKLW-III, parts 2,35). According to the materials, in the research locations of our interest (AJKLW-III, m. 258) the following forms were used: cepa $\left(\mathrm{BG}^{30}\right.$, BS area), cepy (DW, $\mathrm{AD}$ area)" (Kobus 2015a, 142). An analysis of the

\footnotetext{
${ }^{28}$ The variability of the words - cep/cepy - is confirmed indirectly by dictionaries of the contemporary Polish language, see the SDor - cep 'equivalent with cepy', cepy 'a tool for threshing grains consisting of two sticks connected typically with leather straps: a longer one, hand-held and a shorter one which threshes sheaves'; the USJP - cep roln.; see cepy in $1^{\text {st }}$ meaning, cepy - 'a tool for threshing grains consisting of a long wooden handle and attached to it with a leather strap a shorter stick (swingle); cep'; the PSWP-6: cep - 'a primitive tools used to thresh grains, made from a long rod and a shorter rod attached to it with a leather strap'; cepy see cep.

${ }^{29}$ Cf. (Kobus 2010, 142).

${ }^{30}$ In my article (Kobus 2010, 139-146) I analysed contemporary materials from villages that are also considered here the major locations in the TWsp. group of sources: AD - Adamów, Golina commune, Konin
} 
contemporary materials has allowed me to make the following summary: "The recent surveys provide us with slightly different confirmations which are not very unambiguous. They are evidence of the referent's non-existence in rural areas and the omnipresence of the general Polish cep (in DW, a singular use of the cop variant [DuM]). We need to assume that this form prevails in DW and BS. In accordance with the former research, in $\mathrm{AD}$ the form cepy (pl.tant.) prevails as the leading form which, unlike in the previous research, was not recorded in DW. The word cepa (f.) was not recorded in BS while it is still a major form in BG (I will not comment on the hypothetical form in the plural due to a lack of the basic form in the informant's utterance). The form cepa, now used in Dąbrowa, was not recorded before" (Kobus 2015a, 142).

A review of MatStu. (as the control materials) has shown that this source group contains 84 confirmations with cep-, including: masculine gender 27 times (certain), feminine once, plurale tantum 3 times (certain), there is no certainty about the gender in 53 confirmations. The size of the latter group stems from the mode of work of the students who did not ask in this case about the Nominative singular form. The result is a number of replies to the question 'What do you call the old thing to thresh? [cepy // cep // cepa]' in an inflected form: cepami - is it the pl.tant. form (te cepy) or ten cep or ta cepa in singular number? It is difficult to decide about a word which only comes in the plural number; however, the relatively frequent masculine forms draw attention in the light of a much smaller number for feminine gender.

In summary of the considerations of the issue, we can assume that the words for 'a wooden device for threshing grains' show variability in dialects and partly in juxtaposition with the general language. As for temporal changes, it is difficult to evaluate their depth. Starting from A. Tomaszewski, various forms with cep- have been recorded; it seems that the group of prevailing words was evaluated differently. A comparison of the contemporary materials and the survey carried out 30 years after the AJKLW is evidence of a migration of forms recorded in research locations which did not occur there before (or were not recorded). In this respect, this is gender variability.

Let me proceed with another example provided in the TGPnW, namely a phrase $t a$ raza. The historical background of ta raza was covered in the early $20^{\text {th }}$ century in "Poradnik Językowy" where the phrase was not considered a linguistic error (Mańkowski 1901, 108).

The phase has made its way to the dialects and the colloquial language of Wielkopolska. The fact that ta raza/ten raz was included in a questionnaire to the AJKLW 648 is evidence that the phrase has been noted by dialectologists and regarded interesting. 'Tym razem // tą razą // tyn rouz (mu się nie udało)'. In 111 questionnaires, the following results we produced (in some questionnaires there is more than one confirmation so the number of questionnaires/questions does not equal the number of confirmations): no confirmation - 4 times, ta raza - 71, ten raz - 67 .

As the compilation suggests, in the 1970 s the variability of the gender of the phrase in the language spoken in Wielkopolska was a fact. Only four examples differentiate the frequency of both forms provided by the informants, with the prevailing feminine

county, BG - Bukówiec Górny, Włoszakowice commune, Leszno county, BS - Baranówko and Sowinki, Mosina commune, Poznań county, DW - Dąbrówka Wielkopolska, Zbąszynek commune, Świebodzin county. 
form. In atlas research, tą razą was the prevailing form against the general Polish ten raz. This is evidence of the familiar theory that dialects preserve old forms.

At present, the phrase ta raza still exists in the language spoken in villages in Wielkopolska. While it has not been surveyed as a separate subject, it is clearly infrequent and inferior to tym razem. However, the phrase ta raza occurred in lexical surveys of various areas which proves its natural existence in active language of villagers. Below are some examples of randomly selected contemporary texts from various parts of Wielkopolska:

Adamów, KaP - informant born in 1960, KaE - informant born in 1974:

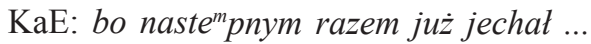

KaP: bo ... bo ... nastepno ${ }^{m}$ razo $^{m}$ podjezdza ... nie ... żeby nie przykryta tych ... tych ziemniaków ziemiom ${ }^{m}$ tego ... no ... gonicha że ta ...

Bukówiec G., MaM - informant born in 1948:

MaM: niektórzy tag na wierzchu to nie zakrywali tylko to zostawili słome ... włożyli tam jakiś kamień $i$ deske ... żeby to parowało niby ... nie ... a my tam nigdy w dómu nie robili tyj ... zaro my przykrywali i kóniec było ... za jedno ${ }^{m}$ razo $^{m} \ldots$ mi sie zdaje już było przykryte i kóniec ...

Modliszewo, PaE - informant born in 1948:

PaE: gospodarz domu czytat ... bo to ... widzi pan ... zależało u kogo była Wigilia ... tego ... to każdy ... za $\mathbf{k a z ̇ d o}^{m}$ razo $^{m}$ Pismo Świe te czytat gospodarz domu ...

The above examples were provided by a group of informants from the II generational brackets which may be an indication of special preference for this form of the phrase among people born in 1945-1970 or the recessive nature of the phase in the feminine form.

Among the confirmations with triple occurrences in the TGPnW and qualifying for an analysis with respect to the gender variability was ta balanza 'balance'. Its equivalent in the general language is balans 'leaning in different directions to keep balance' (the online SJP PWN) i.e. a form in masculine gender. In the TGPnW, ta balanza/ balandza occurred three times against a single confirmation in masculine gender: tyn colki balanc. Therefore, there is a case of gender variability with respect to this example in the dialects spoken in northern Wielkopolska and to the dialect vs. general language opposition. At present, I have not recorded this lexical unit among the informants and, interestingly, the SGP PAN fails to define it, too.

A gender variant which tends to be rare and recorded twice $(+$ feminine gender once) in the analysed volume of dialectal texts, this type is masculine gender from the name of the town of Chodzież. Zofia and Karol Zierhoffer wrote: "The declension of Chodzież, do Chodzieża, sometimes used by the locals, perhaps a slightly transformed original Chodziesz, do Chodziesza" (a. and K. Zierhoffer 1987, 37). The 2 : 1 ratio which indicates the frequency of masculine and the feminine genders in the volume provides grounds for drawing important conclusions. A noteworthy fact is the existing gender variability in the inflection of the word Chodziez that linguists are well aware of. The example has not been subjected to separate surveys. 
This example is the last in a group of confirmations from the TGPnW which occur twice or more times. Below I present the confirmations with single occurrences. I provide comments only on the more interesting names and ones for which I have enough linguistic material.

In the group of confirmations, single occurrences included akacj m. (1), cybul m. (1), "obcy" ga f. (1), gropka f. (1), cygara f. (1), dryla f. (1), pijeca f. (1), krawata f. (1).

Dryla and krawata deserve special attention; both confirmations are feminine.

In the aforementioned monograph Kierunki $i$ dynamika zmian... I presented the evolution of the changes in the thematic sub-area SIEW and, as a result, the names of tools used to sow. In an analysis of the words' occurrence in the selected research locations, earlier (the AJKLW) and now, I have reached the following conclusions: "The time of manual sowing was replaced with a time when the first machines were available to make farming easier. Consequently, a siewka/miska and the human hand were replaced by a horse-drawn sowing device; typically, it was referred to as siewnik konny in Adamów, dryl in Bukówiec G., dryla in Dąbrówka Wlkp. - here the word siewnik was used instead of dryl/dryla. Notably, the word dryl in masculine gender occupies a large part of Wielkopolska, unlike the feminine dryla. However, the latest research provides results different from the atlases; according to the AJKLW III (m. 299), in Dąbrówka Wlkp. one of the used words was dryl (masculine); that dryl should also occur in Adamów which has not been confirmed by contemporary material yet; the word siewnik occurs in the AJKLW as younger than $d r y l / d r y l a$ while the contemporary informants use it as synonyms (but more frequently with respect to a mechanical rather than horse-drawn device). The names of sowing tools are not internally diverse in the specific villages. Similarly, the names of mechanical machines - siewniki - are homogenous in all the villages; the only differentiation in the micro-field in question is for the word indicating a device operating farming devices, ciongnik/traktor" (Kobus 2015a, 155). In northern Wielkopolska, the AJKLW indicated the feminine forms $d r y l-t a d r y l$, sporadically ten $d r y l$ but as a variant with siewnik. Therefore, dryla/dryl are examples of gender variability in dialects and language of villagers. The scarce research sample from the TGPnW does not provide any theories about the dialects in the 1950a - a single occurrence could have been a signal of gender changes in the words for 'a (horse-drawn) seed-drill as indicated by detailed atlas research.

Another word with a sporadic occurrence in the TGPnW is krawata 'a tie'. Ta krawata, confirmed once in the volume, was not a part of the AJKLW or contemporary research. However, the feminine form requires a comment as it is in opposition to the general Polish masculine form ten krawat due to its regional nature. Krawatka is recorded in the w Stownik gwary miejskiej Poznania ${ }^{31}$, in Krakow (the SRK) while the Mały stownik gwar polskich (Wronicz 2010) adds Małopolska (Kolbuszowa county), the Eastern Borderland but fails to mention Wielkopolska.

The remaining examples should be rather viewed as occasional occurrences created by analogy to other words: akacj (Popowo Kościelne), cybul (Strzelce) - both

\footnotetext{
$31<$ http://www.poznan.pl/mim/slownik/words.html?co=word\&word=krawatka (accessed on 18.10.2018)>.
} 
masculine (in general Polish, these are feminine words: akacja, cebula) ${ }^{32}$ and gropka (Wójcin), cygara (Strzelce), pijeca (Popowo Kościelne) - all feminine (in general Polish these words belong to different genders and numbers: grabki pl.tan., cygaro n., piec $\mathrm{m}$.).

From among the above presented lexemes, the AJKLW maps the words for 'an oven for baking bread' (m. 7) - there is no confirmation of feminine gender, grabie as plurale tantum (m. 279 - no grabki form or gropka sing.) and akacja (m. 162), predominantly feminine with a single case of agac for the southern and western parts of the region: "On the south-western peripheries, words with the change of $-k$ - into $-g$-: $\operatorname{agac} 103,105$ occur (...)" (AJKW-II, part 2., 56).

An analysis of old materials does not provide room for observation of the gender diversity on any level. The contemporary material offers more opportunities; it suggests various phenomena taking place in the category of nouns. Perhaps not all the examples are sufficiently representative and the material abundant enough. However, in my opinion the phenomena described further in the article suggest some processes or trends taking place here and now. We do not know it yet but perhaps some of these phenomena or trends will prove a stage of an "evolution" in the course of the development of the grammatical system of the Polish language in its dialectal variants.

Many inflection-related phenomena in language of villagers and related to the gender category are reminiscent of what we are witnessing in the general Polish language. However, there are deviations from this pattern. Some look like single, incidental, even idiolectal patterns; others are repeated frequently enough by the inhabitants of various parts of the region who come from different generations that cannot be treated as incidental.

Let us take a look at several examples: ten/ta przerębel/przerębla, por/pora and seler/selera, pyz/pyza, klusek/kluska, ten/ta cień, ten/ta topól and topól/topola and mysz/mysza, wesz/wsza, brzytew/brzytwa, dratew/dratwa.

Przerębel/przerębla is an example subjected to contemporary gender-related observations. The research was carried out by means of questionnaires distributed among pupils taking part in an educational project ${ }^{33}$ and their families. "(...) we developed a questionnaire aimed at, firstly, developing the level of linguistic awareness and the degree to which the respondents identify their own speech with the local language on the level of declarations (Q. 1: open question, Q. 2-6: multiple choice questions), secondly - confronting the declarations with the actual command of a dialect / knowledge of a dialect (questions about specific words, their meaning, variants etc.). (...) The questionnaire revolves around 23 issues; it was distributed among the pupils of the elementary school in Modliszewko, their families or, possibly, teachers. The questionnaire was voluntary and anonymous, the statistical data included information about the sex, year of birth, time of living in a village. In total, 33 questionnaires were

${ }^{32}$ The forms cebul, akacj are examples of a transfer from soft-stem vowel inflection to consonantal inflection. As M. Brzezina noted, this is a process aligned with the general Middle Polish language which has not ended in dialects yet (Brzezina 1977, 348).

${ }^{33}$ An educational project Holidays, beliefs and superstitions - the language and traditions of villages in Gniezno commune. The questionnaire involved pupils of the elementary school in Modliszewko. 
completed (22 females, 11 males, including 21 children: 12 girls, 9 boys) from Modliszewko (15), Modliszewo (8) and Gniezno (10)" (Kobus, Gniazdowski 2017, 158).

The contemporary materials have a small range, oftentimes limited to a specific village or commune. This method has its benefits and drawbacks. This leads to obtaining material that would facilitate an in-depth analysis of a specific dialect although it limits a quick view of a larger area. This is possible only owing to large-scale research into a specific issue. As it is impossible to confront the words obtained in Modliszewko and their forms with other contemporary confirmations, let me refer to conclusions that I have managed to draw owing to a juxtaposition of old materials. Here are the conclusions: "Questions 9 and 10 revolve around strictly grammatical issues. Question 9 "What do you call a hole cut in the ice?" was aimed at pointing the grammatical gender, a przerębel or a przerębla. Similarly, Question 10 was to indicate the grammatical gender of the word przerębel - ten przerębel or ta przerębel. The effect of the questionnaire is a single confirmation of the form przerębla, in the remaining cases there was a przerębel with phonetic variants: przerębyl, przery ${ }^{m} b l$, przerębt - in total 23 confirmations for przerębel in masculine gender which resulted (and confirmed) in the form of 23 replies to question 10 about Instr. m. sing. - przeręblem with the phonetic variants: przereblym, przyrymlem. One person used in both questions the same word dziura which defies the analysis. This issue is illustrated in m. 746 AJKLW-IX, according to which in that area, ten przerębel masculine prevails although ta przerębel feminine occurs next to wyrab/-ręb" (Kobus, Gniazdowski 2017, 165).

Bogusław Kreja (Kreja 1977, 118-124) referred to the word przerębel with respect to word-formation. On the basis of dialectal materials from Kashubia and Podlasie he deduced that the original form of the word przerębel is feminine, as confirmed by the Sstp and B.S. Linde's dictionary. He indicated przerab (Kreja 1977, 121) as the original form. He also added that the form przerebla “(...) was first noted in Knapski's dictionary (1643), still as an alteration of przerąb (Knapski's przérabl) while the masculine form ten przerębel was first recorded in dictionaries in the $19^{\text {th }}$ century" (Kreja 1977, 122).

The questionnaire distributed among pupils and their families confirmed the fixed nature of the word among the inhabitants of Modliszewko and the surrounds - the masculine form ten przerębel prevails.

The third example or a group of examples, to be more precise: ten/ta por/pora, ten/ ta seler/selera, ten/ta pyz/pyza, ten/ta klusek/kluska, ten lepek/ta łepka, ten listek/to listko.

In Wielkopolska, these words come in a grammatical gender different than in general Polish. Back in the early $20^{\text {th }}$ century, scholars indicated the different gender in these examples as a regional element: "The word seler is used in Wielkopolska in feminine gender as selera, confirmed by Kluk and Jundziłł. In Wielkopolska, pora is also feminine whereas in Eastern Europe Galicia it is por so in plural it would be pory" (Danysz 1914, 246). The forms seler/selera and por/pora was mapped by M. Brzezina; the data on the map suggest that three gender variants were used in Wielkopolska: ten seler and ta selera, ta seler, where seler (m.) and selera (f.) are most common (Brzezina 1982, m. 21). The situation is similar in the second example where the scholar showed two competitive forms por (m.) and pora (f.) (Brzezina 
1982, m. 19). The words por/pora and seler/selera were not subjected to special Wielkopolska research although their presence is still marked in contemporary texts from the region. There are only a few of them in MatStu. and the gender variability is marked (por : pora - 4:5, seler : selera - 3:4). Bearing in mind these data, one could suppose that the feminine form prevails over the masculine one which is evidence of the advantage of the dialect. However, the research sample is too small to decide how the feminine features have survived. It is true that they are still used on a daily basis in Wielkopolska. However, it is hard to evaluate the share of the feminine forms against the general form.

The larger group of confirmations is more interesting: the students asked their informants about the grammatical gender of words recorded in literature on the subject or as a result of field studies in genders different than in the general Polish language. The following conformations appeared: pyz : pyza - 1: 55, klusek: kluska - $0: 49$, ten cień : ta cień - $20: 4$, tepek : tepka - $18: 1$, listek : listko - 55:1, topól/topol : topola $-10: 25$.

The data suggests that the general Polish forms: pyza, kluska, tepek and listek are in enormous advantage over the dialectal and regional pyz, klusek, lepka and listko. Singular confirmations suggest the occasional nature of the masculine or neuter gender. In the cienia/cieni example, it turned out that the general Polish form also prevails over the dialectal one but the representation of four confirmations seems to exclude an incidental nature of the phenomenon.

The last example: ten/ta topól/topola seems to be the most interesting one from a statistical point of view (with the expected advantage of general Polish although not so vast) and for reasons stated above ${ }^{34}$.

In her description of A. Tomaszewski's materials, Monika Gruchmanowa highlighted the lexeme topól: "A. Tomaszewski presented the fluctuations of the gender in the mentioned nouns [ten/ta topůl(a), tyn/ta tynč- JK] in Mowa ludu Wielkopolskiego (p. 36) only generally. The material suggests that the general Polish 'topola' assumes in the dialects of Wielkopolska the form topul. (...) in Wielkopolska, the masculine topuil prevails. The form is most popular in eastern, north-eastern (with fluctuations in Szubin county), north-eastern and western Wielkopolska, reaching to Kramsk. The feminine 'topól' occurs in central (with some fluctuations), western and north-western parts of Wielkopolska. The general Polish form 'topola' occurs in Drawsko (Czarnków county) as an alternation to 'topól' (f.) and in Wijewo (Wschowa county). The Genitive in singular, masculine gender is topola. Only one record stands out, namely kole topolu (Chojna, Wagrowiec county). The Genitive in singular, feminine gender is topoli without an exception" (Gruchmanowa 2003, 36).

There are 45 contemporary conformations with top- to denote 'a tree with heartshaped leaves; often planted in the homestead [topola, topól - (m.//f.)]' but it was impossible to determine the grammatical gender for 13 examples because the informants provided forms in plural which, in many cases, prevented conclusions. The

\footnotetext{
34 The gender variability of the word topól was spotted by A. Tomaszewski and described by M. Gruchmanowa in her article (Gruchmanowa 1959, 3-10) (reprint in (Gruchmanowa 2003, 32-38)). K. Nitsch (Nitsch 1914, 269) also mentioned this example (ta topól).
} 
established proportion is topól/topol : topola - $10: 25$ where topól : topol - 5:5; the gender is definitely masculine in 3 examples of ten topól while in the other examples it is impossible to establish the gender, whether it is ten or ta topól/topol. The forms topól/topol were recorded in the following counties: Jarocin and Gostyń (most frequently), Wągrowiec, Koło, Konin, Kępno. On the other hand, topola was recorded in the counties above as well as in Poznań and Szamotuły (most frequently), Leszno, Czarnków, Świebodzin, Turek, Ostrów Wielkopolski. Consequently, the distribution of these recordings has divided Wielkopolska into an eastern and western part with the border running around Poznań.

As for the materials compiled by A. Tomaszewski (mapped by M. Gruchmanowa in the mentioned article (Gruchmanowa 2003, 36)), they show an extended range of the form topola (recorded before WWII in the north-eastern outskirts of the region, now dispersed all over Wielkopolska although there are locations where it clearly prevails). A. Tomaszewski's materials definitely indicated the prevalence of the form ta topól in the central part of the region with a tendency to move to the north. This fact cannot be verified without further studies

As M. Brzezina noted, the described multi-gender forms ten/ta topól, ten/ta cień “(...) are related to a general dialectal process of soft-stem de-suffixations still in progress” (Brzezina 1977, 357).

Nevertheless, it turns out yet again that dialectal forms are in a minority against the general Polish forms which should not be surprising. The gender variability of the examples in question has also been confirmed. It occurs in relation with the temporal and the geographic levels because it pertains to a language spoken by generations across a territory (the whole of Wielkopolska, an entire dialect and specific dialects). Therefore, there is clear gender variability against the language varieties (general language - dialect - language of villagers).

A word with a formal referent indicating gender other than the ascribed is an interesting phenomenon as indicates the example of wuja which takes the considerations here to the area of regionalisms.

Wuja - this lexical unit is worth mentioning as a curiosity - means 'a male relative, typically a parent's brother but also a male related to the family in a different way; also a family friend', in general Polish wuj, wujek. This is an interesting confirmation (single in the described volume of the TGPnW) because it is feminine only formally, assuming an ending typical of nouns from the feminine inflection (like the three other ones even if they are sanctioned in the general Polish language). Semantically, it does not change its natural gender therefore it is ten wuja. The word is frequently confirmed in contemporary materials, e.g.:

Dąbrówka Wlkp.:

WiW: (...) drożdze wuja muszo ${ }^{m}$ sie ruchać ... nie ...

NiŁ: no to jag mówie ... ty żeź robił ... wuja dojź (?) zeż (?) zrobił ...

Bukówiec G.:

BaK: (...) my gdzieśs som krewni ... nie ... to jez mój wuja ... mamy brat ... nie ... 
WoM: a wuja tu ni ma gdzieś we w tym? ...

SzJ: (...) i tak dzwoni do mnie i mówi ... wuja ... w Bukówcu jes dużo takich ... mówi ... rzemiśników ...

Adamów:

KaP: wuja Witków (?) może by wiedziat ...

LoH: ano wtaśnie ... to też be dzie wuja wiedziat ... i dziadek ...

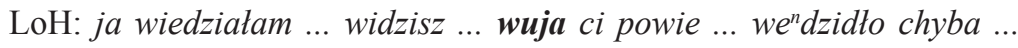

Goraniec:

WeM: jaki wuja miat sprzentu (!) tak powiem nie wiem ... może ten pug $i$ ta brona byta $\ldots$

WeM: ale $w$ Nidomiu zostało dwóch czy czech gospodarzy ... mie ${ }^{n} d z y$ innymi właśnie ten wuja co mówiłam że za tym kieratem chodziłam ...

\section{Strzyżewo Kościelne:}

KwK: (...) stysze taki chichot ... potworny śmiech ... patrze a to wuja Bogdan ... i taki mówie ... i zaraz sie obudziłam ...

These are recordings of utterances of informants from different generations ${ }^{35}$ (in fact representing all the generation brackets - I do not have materials of children's speech but I often hear this form used by representatives of the younger generation) and coexists with wujek and wuj; these two are definitely less frequent than ten wuja. This regionalism is popular all over Wielkopolska. Z. Zagórski (Zagórski 1991, 79-82) also took notice of the popularity of the form wuja among all the informants. Contemporary examples confirm the occurrence of the feminine form ranging from the west to the east of the region, in a broad belt of the meridian orientation. The fact that the word was recorded in the $1950 \mathrm{~s}$ is proof of stability of the form ten wuja. What is more, in 1966 M. Szymczak noted that "In Wielkopolska together with the areas of Sieradz, Kuyavia and Krajna (AJK) there is a form stryja. (...) which is withdrawing from the Wielkopolska dialects very quickly, pushed out by ten wuja" (Szymczak 1966, 7-9).

Interestingly, this characteristic form of the word in question is an example of the feminine inflection only in the Nominative singular form; the inflection follows the masculine pattern, with the Genitive singular tego wuja (rather than tej wuji): do wuja szłam ... (SzA - BG), a tam u wuja byt za stodoło ${ }^{m}$... (PuA-AD), u mojego wuja ...

\footnotetext{
${ }_{35} \mathrm{WiW}-1955, \mathrm{Ni}$ - 1929, BaK - 1947, SzJ - 1925, KaP - 1960, LoH - 1933, WeM - 1952, KwK - 1956. These informants represent two generation brackets - II (born in 1921-1945) and III (1946-1970). As an inhabitant of Wielkopolska, I can confirm the occurrence of the form wuja also in the IV generation brackets and in the youngest language users.
} 
$(\text { WeM-Grc) })^{36}$. M. Brzezina noted that "in dialects, a junction of paradigms is not an exception" (Brzezina 1977, 355). For this reason, the example of wuja is hardly extraordinary although it is not typical, either.

Here I will finish my considerations of gender variability. In my opinion, the descriptions have proven that the phenomena at play continue changes which started in the past and that some of the phenomena are quite new. Not all the deviations from the general Polish language are strictly dialectal, some represent a trend exceeding the limits of a traditional view of a dialect. Not all the questions about the provided examples have been answered even if some of them were observed many years ago, during the atlas studies and earlier (the 1950s, before WWII). I am aware that the subject has not been exhausted but I am also certain that a revision or exclusion of some of the conclusions may result from in-depth and large-scale (general dialectal) research.

\section{Gender variances in words indicating young creatures}

Let me now proceed with strictly synchronous research. A change in the gender of nouns describing young creatures (non-adult creatures) or small objects is an interesting phenomenon observed in the course of contemporary dialectal research. Interestingly, the gender changes when a noun is inflected. The oblique case also reveals grammatical gender different than the expected one (natural or expected in relation with the general Polish norm). I refer to this situation as a gender variance ${ }^{37}$.

MatStu will be used to analyse the issue.

In the excerpted material, gender variances are among the most interesting observations, revealed in the entire region as well as with reference to a smaller area. Beside the above discussed words, this holds true for words of young creatures which

${ }^{36}$ Similar forms are related to mysz/mysza, wesz/wsza, brzytew/brzytwa, dratew/dratwa. This is not about the diversity of the formal and natural genders but rather, the ending of the stem: feminine nouns with stems ending with a consonant. M. Grad-Mucowa (Grad-Mucowa 1970) highlighted the word mysz, referring to this group of nouns in Masovian dialects: "Some of them are levelled with the forms ending in $-a$ as exemplified by myźaź (cf. map 20) and brv́av́ (...). The form myźaź occurs very frequently in other dialects, it is quite common in the south of Poland" (Grad-Mucowa 1970, 51). It turns out that the form mysza, regarded of Masovian and southern-Polish origin, has been used in Wielkopolska. According to the AJKLW, this form was recorded in 13 research locations (hardly incidental then - see the AJKLW: m. 211 'Mysz pronunciation')". "The type mysza (in 13 loc. $m y^{i} \check{s} a, 16,83,93$ and 97 mysa) was recorded in thirteen locations without a geographic pattern, most frequently as a form facultative to the common Wielkopolska type mysz (fem.); only in two locations (loc. 55 near Koło and 97 near Wieruszowo), the form myša (loc. 55) and mysa (97) were recorded as the exclusive form" (AJKLW-II, part 2, 103). This form is also used by the contemporary population of Wielkopolska villages. The word mysz/mysza was examined by students; the two forms coexist in the following ratio: mysz : mysza $50: 5$. The form mysza was recorded in Kępno, Konin, Koło, Ostrów Wielkopolski and Czarnków counties. Other, related examples from the language spoken now in Wielkopolska include wesz : wsza 21 : 16, brzytew : brzytwa 7 : 18 (brzytew Szamotuły county $(\times 3)$, Poznań, Jarocin, Konin, Koło), dratew : dratwa 4 : 25 (dratew Gniezno county (× 2), Wągrowiec, Konin). This rule pertains not only to dialects but also colloquial language. They are examples of a shift from hardstem consonantal inflection to vowel inflection.

${ }^{37}$ In describing this issue, I relied heavily on my article Przydatność studenckich materiałów kwestionariuszowych do badań fleksji gwarowej rzeczownika (Kobus, in press). 
tend to divide Polish regions (as the words are formed with an ending $-e$ and a formant $-a k$ ) into two groups: the northern part with the formant -ak and the southern part with $-e^{38}$. However, this is a gender variance within a single dialectal region. In Wielkopolska, the formant $-a k$ is typical for the southern and western parts (see Tomaszewski 1934, 34). The data from the sources quoted here are variants frequently provided by a single informant or informants from a specific county or even commune: kurczak - kurcze, gonska - go sie - go ${ }^{n}$ sion $^{n}$ tko - gonszczak, kaczuszka - kacze - kaczontko, owieczka - jagnie - jagniontko - jagniok (see Tables 2.1., 2.2., 2.3., 2.4.). In the tables I provide information about the number of all the confirmations (from all the questionnaires - the research included informants from 63 villages) and statistical information in selected research locations under a collective label of a respective county. For better geographic orientation, the names of the counties are accompanied by information about dialectal affinity (east, west, south, central Wielkopolska).

Table 2.1. kurczak - kurcze - kurczon tko

\begin{tabular}{|l|c|c|c|}
\hline \multicolumn{1}{|c|}{ county / part of region } & $\begin{array}{c}\text { variant I } \\
\boldsymbol{k u r c z a k}\end{array}$ & $\begin{array}{c}\text { variant II } \\
\boldsymbol{k u r c z e}\end{array}$ & $\begin{array}{c}\text { variant III } \\
\boldsymbol{k u r c z o}_{\boldsymbol{n}} \boldsymbol{t} \boldsymbol{c} \boldsymbol{\text { o }}\end{array}$ \\
\hline all surveyed & 72 & 50 & 23 \\
\hline Koło / east Wlkp. & 2 & 6 & 1 \\
\hline Konin / east Wlkp. & 6 & 6 & 0 \\
\hline Gostyń / south Wlkp. & 12 & 8 & 1 \\
\hline Leszno / south Wlkp. & 5 & 4 & 0 \\
\hline Jarocin / central Wlkp. & 4 & 1 & 1 \\
\hline Poznań / central Wlkp. & 9 & 4 & 2 \\
\hline Szamotuły / central Wlkp. & 4 & 2 & \\
\hline
\end{tabular}

Table 2.2. $g o^{n} s k a-g o^{n}$ sie $-g o^{n}$ sio $^{n} t k o-g o^{n}$ szczak

\begin{tabular}{|l|c|c|c|c|}
\hline county / part of region & $\begin{array}{c}\text { variant I } \\
\boldsymbol{k u r c z a k}\end{array}$ & $\begin{array}{c}\text { variant II } \\
\boldsymbol{k u r c z e}\end{array}$ & $\begin{array}{c}\text { variant III } \\
\boldsymbol{k u r c z o}^{\boldsymbol{n}} \text { tko }\end{array}$ & $\begin{array}{c}\text { variant IV } \\
\boldsymbol{g o}^{\boldsymbol{n}} \boldsymbol{s z c z a k}\end{array}$ \\
\hline all surveyed & 37 & 7 & $55(1)$ & 14 \\
\hline Koło / east Wlkp. & 3 & 0 & 0 & 1 \\
\hline Konin / east Wlkp. & 0 & 1 & 4 & 5 \\
\hline Gostyń / south Wlkp. & 3 & 1 & 6 & 0 \\
\hline Leszno / south Wlkp. & 0 & 1 & 4 & 0 \\
\hline Jarocin / cent. Wlkp. & 4 & 0 & 4 & 2 \\
\hline Poznań / cent. Wlkp. & 2 & 0 & 4 & 0 \\
\hline $\begin{array}{l}\text { Szamotuły / } \\
\text { central Wlkp. }\end{array}$ & 0 & 0 & & \\
\hline
\end{tabular}

${ }^{38}$ B. Osowski (Osowski 2015, 97-128) described the issue based on materials from the $18^{\text {th }}$ century. Reference to (Taszycki 1934, 20). 
Table 2.3. kaczuszka - kacze - kaczontko

\begin{tabular}{|l|c|c|c|}
\hline \multicolumn{1}{|c|}{ county / part of region } & $\begin{array}{c}\text { variant I } \\
\text { kurczak }\end{array}$ & $\begin{array}{c}\text { variant II } \\
\text { kurcze }\end{array}$ & $\begin{array}{c}\text { variant III } \\
\text { kurczon } \text { tko }^{-}\end{array}$ \\
\hline all surveyed & 46 & 12 & 62 \\
\hline Koło / east Wlkp. & 3 & 2 & 3 \\
\hline Konin / east Wlkp. & 6 & 4 & 5 \\
\hline Gostyń / south Wlkp. & 4 & 1 & 7 \\
\hline Leszno / south Wlkp. & 1 & 1 & 3 \\
\hline Jarocin / cent. Wlkp. & 4 & 0 & 7 \\
\hline Poznań / cent. Wlkp. & 4 & 0 & 3 \\
\hline $\begin{array}{l}\text { Szamotuły / } \\
\text { central Wlkp. }\end{array}$ & 4 & 0 & 3 \\
\hline
\end{tabular}

Table 2.4. owieczka - jagnie - jagniontko - jagniok

\begin{tabular}{|l|c|c|c|c|}
\hline \multicolumn{1}{|c|}{ powiat / część regionu } & $\begin{array}{c}\text { variant I } \\
\text { owieczka }\end{array}$ & $\begin{array}{c}\text { variant II } \\
\text { jagnie (jagle) }\end{array}$ & $\begin{array}{c}\text { variant III } \\
\text { jagniontko }\end{array}$ & $\begin{array}{c}\text { variant IV } \\
\text { jagniok }\end{array}$ \\
\hline all surveyed & 15 & $53(5)$ & 49 & 1 \\
\hline Koło / east Wlkp. & 0 & 4 & 4 & 0 \\
\hline Konin / east Wlkp. & 4 & 7 & 7 & 0 \\
\hline Gostyń / south Wlkp. & 2 & 6 & 7 & 0 \\
\hline Leszno / south Wlkp. & 1 & 4 & 1 & 0 \\
\hline Jarocin / cent. Wlkp. & 0 & $1(3)$ & 4 & 0 \\
\hline Poznań / cent. Wlkp. & 2 & 5 & 3 & 0 \\
\hline $\begin{array}{l}\text { Szamotuły / } \\
\text { central Wlkp. }\end{array}$ & 0 & $3(2)$ & 2 & 0 \\
\hline
\end{tabular}

The conclusions drawn from the tables above lead to a theory that in Wielkopolska, words for young creates with the formant -ak for kurczak and go ${ }^{n}$ szczak prevail, especially in the southern and central research locations in the region and with the referent -e (e) for jagnie (kurcze enjoys also many confirmations) without more distinct trends in the dialect, resulting from the fact that the data are not sufficiently diverse with respect to the area.

The distribution of gender forms in words denoting young creatures seems much more interesting. Numbers are a relatively representative referent of frequency of use and indicate high actual variability.

As for the words denoting 'a hen's offspring', among the three variants, words like the masculine kurczak (72) prevail although neuter nouns like kurcze (50) and kurczont$k o$ (23) are also frequent. In the example related to 'a goose's offspring', four variants in three genders were recorded, where variant $\mathrm{I}$ is a diminutive of the adult feminine creature $g o^{n} s k a$ (37), half the number (but still many) of indications in masculine 
gender gonszczak (14), while the biggest number of indications was of neuter gender with the prevailing variant $g o^{n} \operatorname{sio}^{n} t k o / g e^{n} \operatorname{sio}^{n} t k o(55: 1)$ and the rare gon sie (7). The collection of words for 'a young duck' consists of feminine words formed also by means of a diminutive of a female adult creature - kaczuszka (46) and the prevailing neuter words kaczontko (62) and kacze (12). The last example is related to words denoting 'a sheep's offspring' and is represented by four variants out of which the feminine ones are formed like the nouns above by means of diminutives of feminine adult features - owieczka (15) - and are rather rare in comparison with neuter words like jagnie/jagle (53:5) and jagnio ${ }^{n}$ tko (49); masculine gender is represented by the single confirmation jagniok.

An analysis of the excerpted examples of words for young creatures leads to a conclusion that many (if not most) of the informants who provided the Nominative form, did not indicate more than one word. The gender changes when the oblique form appears inflected, other than the Nominative (of course this is not the norm). Below are some examples showing the pattern (see Table 2.5).

Table 2.5. Gender variance and word inflection (MatStu.)

\begin{tabular}{|c|c|c|c|c|}
\hline location & referent & $\begin{array}{l}\text { form in Nom. } \\
\text { singular or Nom. } \\
\text { plural (gender) }\end{array}$ & $\begin{array}{l}\text { form in Gen. } \\
\text { singular or Gen. } \\
\text { plural (gender) }\end{array}$ & $\begin{array}{l}\text { change in } \\
\text { gender }\end{array}$ \\
\hline Powiercie, Koło county & a hen's young & kurcze (n.) & kurczaka (m.) & n. $\rightarrow \mathrm{m}$. \\
\hline Gostyń, Gostyń county & a hen's young & kurczaki (m.) & kurcze (n.) & $\mathrm{m} . \rightarrow \mathrm{n}$ \\
\hline $\begin{array}{l}\text { Pogorzela, Gostyń } \\
\text { county }\end{array}$ & a hen's young & $k_{\text {urcze }}^{n} t a(\mathrm{n})$. & $\begin{array}{l}\operatorname{kurcze}^{n} \operatorname{cia}(\mathrm{n} .) \\
\operatorname{kurczaka}(\mathrm{m} .)\end{array}$ & n. $\rightarrow \mathrm{m}$. \\
\hline $\begin{array}{l}\text { Szczurowice, Ostrów } \\
\text { Wlkp. county }\end{array}$ & a hen's young & $k u r c z e^{n} t a$ (n.) & kurczaka (m.) & n. $\rightarrow \mathrm{m}$. \\
\hline $\begin{array}{l}\text { Odolanów, Ostrów } \\
\text { Wlkp. county }\end{array}$ & a hen's young & $\begin{array}{l}\text { kurczak (m.) } \\
\text { kurcze (n.) }\end{array}$ & kurczontka (n.) & $\mathrm{m} . \rightarrow \mathrm{n}$ \\
\hline Powiercie, Koło county & a goose's young & $g^{\prime}{ }^{n}$ sio $^{n}$ tko (n.) & $g o^{n} \operatorname{sek}$ (f.) & n. $\rightarrow \dot{\text { Ż. }}$ \\
\hline Stefanów, Jarocin county & a goose's young & $g o^{n} s k a$ (f.) & $g o^{n} \operatorname{sio}^{n} t$ (n.) & f. $\rightarrow$ n. \\
\hline $\begin{array}{l}\text { Koszkowo, Wyrzysk } \\
\text { county }\end{array}$ & a goose's young & $g o^{n}$ szczak (m.) & $g o^{n} \operatorname{sio}^{n} t$ (n.) & $\mathrm{m} . \rightarrow \mathrm{n}$. \\
\hline $\begin{array}{l}\text { Pogorzela, Pogorzela } \\
\text { county }\end{array}$ & a goose's young & $g o^{n} s k i$ (f.) & $g o^{n} \operatorname{sio}^{n} t$ (n.) & f. $\rightarrow$ n. \\
\hline Kawcze, Rawicz county & a goose's young & $\begin{array}{l}g o^{n} \operatorname{sie}^{n} t a(\mathrm{n} .) \\
g o^{n} \text { ski (f.) }\end{array}$ & $g o^{n} \operatorname{sio}^{n} t$ (n.) & f. $\rightarrow \mathrm{n}$. \\
\hline $\begin{array}{l}\text { Słomczyce, Słupca } \\
\text { county }\end{array}$ & a sheep's young & jagniontka (n.) & owieczków (f.) & n. $\rightarrow$ f. \\
\hline Dębe, Kalisz county & a sheep's young & $\begin{array}{c}\text { owieczki (f.) } \\
\text { jagnióntka (n.) }\end{array}$ & jagniontek (n.) & $\mathrm{f} . \rightarrow \mathrm{n}$. \\
\hline $\begin{array}{l}\text { Gniezno, Gniezno } \\
\text { county }\end{array}$ & a sheep's young & jagnie (n.) & $\begin{array}{c}\text { owieczek (f.) } \\
\text { jagniontek (n.) }\end{array}$ & n. $\rightarrow$ f. \\
\hline
\end{tabular}




\begin{tabular}{|c|c|c|c|c|}
\hline $\begin{array}{l}\text { Pogorzela, Gostyń } \\
\text { county }\end{array}$ & a sheep's young & jagnion tko (n.) & $\begin{array}{l}\text { owieczek (f.) } \text { jegnie }^{n} \text { ty (n.) } \\
\text { jagnio }^{n} \mathrm{t}(\mathrm{n} .)\end{array}$ & n. $\rightarrow$ f. \\
\hline Golina, Konin county & a sheep's young & $\begin{array}{l}\text { owieczka (f.) } \\
\text { jagnie (n.) }\end{array}$ & jagnio $^{n} t$ (n.) & f. $\rightarrow$ n. \\
\hline $\begin{array}{l}\text { Koszkowo county } \\
\text { Wyrzysk }\end{array}$ & a duck's young & $k a c z o^{n} t k o$ (n.) & $\begin{array}{l}\text { kaczontek (n.) } \\
\text { kaczek (f.) }\end{array}$ & n. $\rightarrow$ f. \\
\hline $\begin{array}{l}\text { Gniezno, Gniezno } \\
\text { county }\end{array}$ & a duck's young & $k a c z o^{n} t k a(\mathrm{n})$. & $\begin{array}{l}\text { kaczontków (n.) } \\
\text { kaczuszek (f.) }\end{array}$ & n. $\rightarrow$ f. \\
\hline $\begin{array}{l}\text { Święciechowa, Leszno } \\
\text { county }\end{array}$ & a duck's young & kacze (n.) & $\begin{array}{c}\text { kaczek (f.) } \\
\text { kaczuszek (f.) }\end{array}$ & n. $\rightarrow$ f. \\
\hline $\begin{array}{l}\text { Witaszyce, Jarocin } \\
\text { county }\end{array}$ & a duck's young & kaczuszki (f.) & $\begin{array}{l}\text { kaczuszków (f.) } \\
\text { kaczonek (n.) }\end{array}$ & f. $\rightarrow$ n. \\
\hline Gostyń, Gostyń county & a duck's young & kaczuszki (f.) & $k a c z o^{n} t$ (n.) & f. $\rightarrow$ n. \\
\hline
\end{tabular}

The material presented in the table above shows clearly that the change in gender, taking place in the course of inflection, involves in many cases also a formal change not only with respect to word forming (e.g. kurcze $\leftrightarrow$ kurczak; kacze $\leftrightarrow$ kaczatko; gasiatko $\leftrightarrow$ gaszczak; jagnię $\leftrightarrow$ jagniątko) but also in the realm of vocabulary (e.g. jagnię, jagniątko $\leftrightarrow$ owieczka; kaczę, kaczątko $\leftrightarrow$ kaczuszka; gasiątko, gąszczak $\leftrightarrow$ gąska).

The forms in the Genitive plural offer even greater dynamics of forming words denoting young creatures. The forms recorded by students indicate the difficulty encountered by the informants in creating words according to the system. More and more frequently, they tend to escape the complexity by providing erroneous replies or no replies at all; some informants resort to creating words for young creatures by means of diminutives of the adult creatures or by deforming the names of young creatures formed in line with the system. This issue is illustrated in Table 2.6. with questions and replies excerpted from the recordings.

Table 2.6. Forms in the Gen. plural of young creatures in MatStu.

\begin{tabular}{|c|c|c|c|c|c|}
\hline question & $\begin{array}{c}\text { form } 1 \\
(-o ́ w)\end{array}$ & $\begin{array}{c}\text { form } 2 \\
(-\theta)\end{array}$ & $\begin{array}{l}\text { form } 3 \\
\text { (other) }\end{array}$ & deficiencies & defects \\
\hline $\begin{array}{l}\text { Typically, a duck } \\
\text { leads many ... } \\
\text { (kacząt, kaczątków, } \\
\text { kaczętów). }\end{array}$ & $\begin{array}{c}\text { kaczontków (6) } \\
\text { kaczuszków (3) } \\
\text { kaczoków (1) }\end{array}$ & $k a c z o^{n} t(17)$ & $\begin{array}{l}\text { kaczontek (17) } \\
\text { kaczuszek (16) }\end{array}$ & 7 & $\begin{array}{c}17 \\
\left(\text { kaczek }^{10},\right. \\
\text { kaczków 3, }_{\text {kaczy }} \text { tka 1, } \\
\text { pisklo } t \text { 3) }^{n}\end{array}$ \\
\hline $\begin{array}{l}\text { Many times, a sheep } \\
\text { does not have one } \\
\text { young but several... } \\
\text { (jagniąt, jagniętów). }\end{array}$ & $\begin{array}{l}\text { jagle tów (1) } \\
\text { owieczków (1) }\end{array}$ & $\begin{array}{l}\text { jagnio }^{n} t(34) \\
\text { owczon }^{n} t(1)\end{array}$ & $\begin{array}{l}\text { jagniontek (8) } \\
\text { owieczek (10) }\end{array}$ & 4 & $\begin{array}{c}6 \\
\left(\text { jagly }^{n} \text { ta } 1,\right. \\
\text { jagniontka } 2, \text {, } \\
\text { owieczki 1, } \\
\text { jagnie 2, } \\
\text { jagnie ty 1, } \\
\text { jagna 1, } \\
\text { owców 1, } \\
\text { owiec 1) }\end{array}$ \\
\hline
\end{tabular}




\begin{tabular}{|c|c|c|c|c|c|}
\hline $\begin{array}{l}\text { When a goose has } \\
\text { many young ones } \\
\text { people say it has } \\
\text { many ... (gassiąt, } \\
\text { gasków, gaszczoków, ?). }\end{array}$ & $\begin{array}{c}g o^{n} \text { sków (2) } \\
g o^{n} \text { szczoków } \\
\text { (6) }\end{array}$ & $\begin{array}{l}g^{n} \operatorname{sio}^{n} t(30) \\
g o^{n} \operatorname{szczo}^{n} t \text { (1) }\end{array}$ & $\begin{array}{c}\text { go } o^{n} \text { sio }^{n} \text { tek (9) } \\
\text { go } o^{n} \text { sek (15) }\end{array}$ & 6 & $1($ pisklo $t)$ \\
\hline
\end{tabular}

The general Polish forms prevail here, accompanied by words formed from dialectal names in line with the general language norm, e.g. kaczoków, gonszczoków. The remaining -ów endings are dialectal: kaczontków, kaczuszków, jaglentów, owieczków, gonsków.

In fact, each of the three examples from the survey has six variants among which at least three (half of them) are dialectal variants (although not always with a dialectal ending):

- dialectal kaczontków (6), kaczuszków (3), kaczoków (1) next to general Polish: kaczon $^{n}$ (17), kaczontek (17), kaczuszek (16);

- dialectal jaglentów (1), owieczków (1), owczont (1) next to general Polish: jagnion $t$ (34), jagniontek (8), owieczek (10);

- dialectal gon sków (2), gon szczoków (6), go ${ }^{n} s z c z o^{n} t$ (1) next to general Polish: $g o^{n-}$ sio $^{n} t$ (30), go ${ }^{n}$ sio $^{n}$ tek (9), go ${ }^{n}$ sek (15).

Next to the dialect : general Polish opposition, there are also formal variants within these words. (16);

- kaczontków (6) : kaczon $^{n}$ (17) : kaczontek (17) and kaczuszków (3) : kaczuszek

- jagniont (34) : jagniontek (8) and owieczków (1) : owczo ${ }^{n}$ (1) : owieczek (10);

- go sio $^{n} t$ (30) : gon sio $^{n}$ tek (9), go ${ }^{n}$ Szczoków (6) : go ${ }^{n}$ szczo ${ }^{n}$ (1) and go ${ }^{n}$ sków (2) : gon ${ }^{n}$ sek (15).

The dialectal forms in these examples are always in a minority, irrespective of their endings. This great variability indicates the extremely dynamic nature of this group of words; the chances that the forms with -ów will prevail in dialects are slim for two major reasons: 1) general forms are definitely not inferior to dialectal forms, the proportions of the confirmations leave no doubt about the domination of the norm, 2) the words for young ducks, geese and sheep in the dialectal form could be better represented in the language system if they were more widely used in the extra-linguistic context. Meanwhile, the number of these farm animals is clearly diminishing in individual farms (few farmers grow poultry for their own needs, sheep are practically not kept anymore), the dialectal words will withdraw together with their users i.e. elderly people (young people are not willing to use the problematic dialectal forms, having at their disposal regular general Polish words inflected).

Let me go back to the major issue of discussion, the gender and Table 2.5. The most frequent changes to gender in the material at hand occur between feminine and neuter genders; there are seven transitions of the type f. $\rightarrow$ n. and n. $\rightarrow$ f., each. The number of changes between neuter and masculine genders is much smaller, three of each: $\mathrm{n}$. $\rightarrow \mathrm{m}$. and $\mathrm{m}$. $\rightarrow \mathrm{n}$. There is no relation between feminine and masculine genders which theoretically is possible. Perhaps extending the research sample would indicate this type of change. 
The material at my disposal (the entire material compiled by students, not only from the table related to the gender variance and inflection of words) may not seem very ample but it allows to deduce that in the formation of words denoting young creatures in the language spoken by young people from Wielkopolska, neuter gender prevails (in accordance with the grammars of the general Polish language). One can also venture a statement that inflecting certain basic forms becomes too difficult so it is easier to select an oblique form, easier to form for different reasons although resulting in a lexical or gender-related change (selection of the form and the concept of the level of difficulty of creating oblique forms seems to be strictly individual). However, the materials allow to exclude the idiolectal or even incidental nature of the described phenomenon. The analysed linguistic data come from various research locations from Wielkopolska which gives reason to consider the phenomenon a dialectal feature. It would be interesting to know the results of research into this phenomenon in other dialects.

\section{The opposition between masculine and non-masculine plural forms - a problem with differentiating gender classes}

The dialect users' inability to differentiate between the masculine and non-masculine gender has been largely covered in dialectal inflection. Hanna Jadacka called non-masculine forms of the type chtopy, doktory, profesory, grammatically "deformed" (Jadacka 2006, 20). These issues were described in dialects and the general language in the 1970 s and the 1980 s by J. Zieniukowa in numerous publications (Zienukowa $1968,109-114 ; 1975,70-93 ; 1974 a, 87-123$; 1974b, 55-63) which resulted in a monograph Rodzaj męski osobowy we współczesnych językach zachodniosłowiańskich (Zieniukowa 1981), and Z. Saloni (Saloni 1988, 155-166). This issue in dialects was covered by Z. Zagórski (Zagórski 1991) and Halina Pelcowa (Pelcowa 1977, 335-342) and, more recently, by Alina Kępińska (Kępińska 2006) and Łukasz Szałkiewicz (Szałkiewicz 2010, 220-221) 39, Danuta Makowska (Makowska 2008, 205-226) and D. Makowska and Z. Saloni (Makowska, Saloni 2009, 145-158), as well as Danuta Skowrońska (Skowrońska 2011, 284-293). The authors of the latest publications avoid

39 Ł. Szałkiewicz provided a review of theories related to a depreciative approach to non-masculine plural forms. The scholar referred to the concepts of Z. Saloni: "Saloni emphasised the fact that depreciative forms are formed completely regularly. Therefore, from the grammatical (systemic) point of view, all the nouns mos inflected by the number have depreciative forms in the Nominative plural. (...) Saloni took a step further; he decided that every masculine noun has also a non-depreciative form. This theory is even more controversial and the author devotes a majority of his article to it (Saloni 1988: 160-161, 164-165)"; further on he also referred to a theory by H. Jadacka included in Nowy stownik poprawnej polszczyzny PWN, A. Markowski (ed.), Warszawa 2003: "The coexistence of personal and impersonal endings, frequent in the Nominative of masculine nouns, is motivated by the style - negative, common and positive forms receive a material ending as an inflection discriminant, e.g. chłopy, dyrektory, ministry, policjanty, studenty, while the neuter use is signalled by a masculine referent, e.g. chłopi, dyrektorzy, ministrowie, policjanci, studenci. (...) The style-related mechanism refers here to a series of two-gender forms $-a$ where the emotional load is related to the lexemes themselves rather than to their inflection forms, e.g. beksy, gapy, lamagi, marudy (...). In this case, the functional-stylistic criterion would determine the selection of the inflection element (NSPP: 1681)" (Szałkiewicz 2010, 224). 
references to dialectal materials and contemporary data obtained in rural areas. What is more, the issue of mixing masculine and non-masculine forms in the Nominative plural of masculine nouns have been lately viewed primarily in the context of depreciation.

In this chapter I would like to suggest a slightly different view of the opposition $c i$ : te in masculine gender plural, namely not as depreciation or non-depreciation, or in the context of the category. I would also refute stylistic considerations. I agree with Z. Zagórski that "(...) the category of masculine plural is an intermediate inflection-syntactic category. Therefore I study the opposition: masculine plural - non-masculine plural or a lack of the opposition, starting with specific syntactic structures and elements of the structure, taking into account the desired extent of inflection elements (on a lower level)" (Zagórski 1991, 29). In my opinion, the structure te chlopy robity/-li in the language spoken in Wielkopolska is a predominantly syntactic issue from the point of view of grammar, without stylistic considerations. This is because the speakers' intention is not depreciation (presence of a form in accordance with the general Polish pattern should be treated as a variant rather than an invariant). Of importance here are semantics. There are no problems with differentiating the masculine and non-masculine plural because this is not about taking a look at dialects from the point of view of the general Polish norm - te chtopy robity from the point of view of the "norm" of language of villagers is a correct phrase (po naszymu) ${ }^{40}$. I suggest looking at the relation between the two genders in dialects and in other Polish dialects. This theory is corroborated by examples from dialectal materials where there are no opposition pairs that would allow any choice (i.e. there is one way of expressing a message). This state changes as the linguistic awareness of the users of a local variety of Polish grows, to be evidenced by the material presented below.

Of interest are examples from Wielkopolska texts and the remaining linguistic data like the already analysed volume of the TGPnW, the KwAJKLW and contemporary continuous texts (TWsp.).

In the TGPnW I have found $49(27 / 16+6)$ examples confirming the above presented phenomenon (14 different words: nieboszczyki, goście (te) : goście (ci), chłopy : chłopi, k'ośniki : kośnicy, krawce : krawcy, kawalery/kawalerzy (te) : kawalerzy (ci), so ${ }^{m}$ siady : so ${ }^{m}$ siedzi, drużby : drużbowie, króle : królowie, ludzie (te) : ludzie (ci), parobki : parobcy, rzeźniki : rzeźnicy, rodzice (te) : rodzice (ci), mtyunarze (te) : mtynarze (ci)). The numbers in brackets have the following meaning: 27 indicates "untypical" lexical units whose form in the Nominative plural are different from the general Polish language, 16 following a slash indicate the number of words whose different gender stems from syntactic conditioning. It is communicated by the pronoun, verb or adjective, 6 is a number of examples compliant with the norm in the general Polish language.

Statistical data are not very numerous in a majority of examples. In a detailed analysis I have used examples recorded at least three times. In general conclusions, I will consider the entire excerpted material.

\footnotetext{
${ }^{40}$ The TGPnW provides also phrases related to a change of gender (against the general Polish language) for feminine nouns in the Nominative plural: On jóż [!] byel ostrożny z tym bo to krowy już tam sie zatkali ... panie ... (p. 29), To byli ty pijyrsie ... (p. 15).
} 
One could say that in the TGPnW, the non-masculine forms in the Nominative plural of masculine nouns prevail over masculine forms in line with the general Polish norm. In some examples (te goście, te drużby, te chłopy, te rodzice, te kawalery/te kawalerzy) the advantage is considerable. The example te ludzie : ci ludzie recorded in the TGPnW 32 times looks interesting although only in five examples was it possible to determine the right gender, resulting in a proportion $3: 2$ for the dialectal form. The situation is similar for the example te goście : ci goście recorded in the texts 9 times but only in 6 examples was it possible to determine the gender unambiguously which resulted in a ratio $4: 2$ for the non-masculine form. In the example te rodzice : $c i$ rodzice non-masculine forms also prevail - there is a clear $6: 1$ ratio. Attention should also be drawn to te chtopy and te druzby which appeared in the texts as the exclusive forms of nouns chłop and drużba. The example te kawalery/te kawalerzy presents a situation where all the examples prove to be non-masculine: two because of the form and one (formally ogp.) owing to the syntactic exponent, in this case the pronoun te (kawalerzy). The remaining examples - single, possibly double - confirm the occurrence of non-masculine forms in the described category of nouns but there is not enough of them to define their exclusive or sporadic nature (nieboszczyki, $k^{u} o s ́ n i k i, k r a w c e, s o^{m} s i$ ady, parobki, rzeźniki, mtyunarze); only the example króle : królowie can be treated as a signal that the prevalence of non-masculine forms in the Nominative plural of masculine nouns in Wielkopolska dialects in the 1950s is not so monolithical.

Let me therefore check if the well-established prevalence of the described forms has the same status in the speech of informants examined 20-30 years later.

Unfortunately, in the case of atlas data there are even fewer examples to compare. Among the examples in the TGPnW, the questionnaire asked only about goście, króle, ludzie, with added fszyskie sfiy ${ }^{n} t e$. For the sake of the analysis, I have adopted four examples with many conformations. The data suggests that the forms te goście are in a minority in relation with ci goście, as in the examples te ludzie : ci ludzie and fszyskie świynte: fszyskich świntych. An entirely different result (44:0) is reflected in the example te króle : ci królowie referring to Epiphany.

To sum up this group of sources one could say that the non-masculine nature in the discussed nouns is highly irregular (the proportions did not indicate zero values except for one example) with prevailing general Polish forms.

How do the described forms operate in contemporary language of villagers? In the analysed set of contemporary dialectal texts I checked the occurrence of the same examples which appeared in texts from the 1950s and the example Wszystkich Siwientych checked in the KwAJKLW (in this specific example I used an additional group of transcriptions collected directly for holidays throughout the year in an educational project carried out around Gniezno).

In contemporary texts there are no confirmations for all the examples derived from the TGPnW - there are no confirmations for the Nominative plural for króle, krawce, ${ }^{41}$. On the other hand, druzby and kawalery, nieboszczyki had a very low frequency, where

${ }^{41}$ In general, the form nieboszczyki operates now in language of villagers - it appeared in Modliszewko (Gniezno commune and county). Here I analyse a fixed group of source materials and in these texts, the form was not recorded. 
for drużby there is only confirmation of the general Polish form (drużbowie x 2). In the second example, there is a non-masculine form of a noun with the accompanying masculine syntactic determinant niektórzy kawalery while the form nieboszczyki appeared only once. The frequency of the remaining examples leads to certain conclusions. Therefore we can acknowledge the prevalence (and even exclusivity) of the general Polish forms for the examples: ludzie, rzeźnicy, rodzice, Wszystkich Świętych, gospodarze (this example was not regarded in the TGPnW or KwAJKLW). It is hard to say to what extent the lexeme goście - te occurs against ci goście. There is a proportion 4: 2 for the first form; while value 2 does not raise doubts, value 4 can be regarded the number determining unspecified nouns with respect to the gender in two out of four recordings because they are forms without a context that would eradicate all ambiguity (while the phrase $i z ́$ w goście is clear about non-masculine gender, in an utterance to znaczy że goście przyjado ${ }^{m}$... this certainty disappears). It is therefore advisable to take a closer look at the remaining examples, i.e.: chłopy, kośniki, so ${ }^{m} s i$ $a d y$, parobki where the non-general Polish form definitely prevails.

In the four examples in question, the opposition between masculine - non-masculine plural is very distinct; in the example ci chłopi : te chłopy there is a proportion 2 : 43, ci kośnicy : te $k^{u}$ ośniki proportion $5: 8$, ci son siedzi : te so ${ }^{m}$ siady proportion $0: 6$, and ci parobcy : te parobki - 1:3. The value of non-masculine plural has an interesting distribution. There is a division into: A. the number of recordings in the form of a non-masculine noun together with a syntactic determinant (verb, pronoun, possibly an adjective) confirming the gender, e.g. chtopy jak ... wi pan co ... na wsi ... nie ... jak byty tag nauczóne ... że jak poczuty ... (BG - SoF); B. the number of recordings in the form of a non-masculine noun together with the syntactic determinant (a verb, a pronoun, possibly an adjective) which denies this gender (hybrid ${ }^{42}$ ), e.g. chtopy sie narobili... (AD - WoS); C. the number of recordings in the form of a non-masculine noun without additional syntactic determinants confirming or excluding this gender, e.g. bo chlopy to tag za duzo nie lubióm ... (BG - SoA). In the four examples in question, the confirmations assumed the following values (the number after the colon denotes the number of the general Polish forms - ogp.):

te chłopy : ci chtopi $(43: 2) \rightarrow 15$ A / 19 B / 9 C : 2 ogp.

te kuśniki : ci kośnicy (8:5) $\rightarrow 1 \mathrm{~A} / 4 \mathrm{~B} / 3 \mathrm{C}: 5$ ogp.

te so $^{m}$ siady : ci sonsiedzi $(6: 0) \rightarrow 1 \mathrm{~A} / 3 \mathrm{~B} / 2 \mathrm{C}: 0$ ogp.

te parobki : ci parobcy $(3: 1) \rightarrow 2 \mathrm{~B} / 1 \mathrm{C}: 1$ ogp.

In the first three examples, there are three combinations of non-masculine gender in masculine nouns in the Nominative plural. In the fourth example, probably the small research sample affected the lack of combination A. In the example best exemplified in contemporary texts (chtopy), the hybrid combination (B) prevails which is also best represented in the remaining two examples ( $k^{u}$ ośniki and so ${ }^{m} \operatorname{siady}$ ). The

${ }^{42}$ In her article Konstrukcje hybrydalne typu stare profesory wiedzieli, młode doktory pytali $w$ języku polskim, D. Skowrońska (Skowrońska 2011, 284-293) used a term hybrid structures: "This notion means any combination of depreciative forms (and, by analogy, non- depreciative) with masculine (by analogy: non-masculine) forms of adjectives, verbs and numerals" (Skowrońska 2011, 285). The scholar disregarded dialectal materials. In my opinion, a hybrid is a combination of these elements but without associating them with the depreciation category. 
significant presence of option B (hybrid) may be evidence that the opposition of the two genders discussed here is not stable in the contemporary language spoken in Wielkopolska. This theory is also corroborated by (few) utterances where the combinations A and B (and C as it is) are expressed at the same time in a single short message (the examples come from people from generation II, from Bukówiec G.: [SzJ] - a male born in 1925 and [LiE] - a woman born in 1935 and Adamów [LoH] - a woman born in 1933):

SzJ: bo te ... te kośniki no to oni tag ro... rozrzucili ...

LiE: $i$ to takie specjalne chtopy juz byliy ...

LoH: to byty takie ludzie ... którzy urok ... rzucali ...

The examples show a strong influence of semantics on the syntax of the utterances. We can assume that masculine gender in singular which is obvious for a language of villagers user in the examples kośnik, chtop (and having a natural affiliation with the words), determines that the predicate is used in masculine gender, despite the subject and the accompanying attribute reinforcing non-masculine gender. We cannot decide if the generation affinity of the quoted informants is of any significance here and to what extent, but the fact that in the other generation brackets this phenomenon has not been recorded, may trigger off further search.

An analysis and interpretation of the materials prove that the non-masculine category in language of villagers is disorderly for masculine nouns in the Nominative plural.

The materials presented in table I.1.3. from three different periods are a mosaic of masculine and non-masculine forms in the Nominative plural in the group of masculine personal nouns. In general, a majority of examples, old and contemporary, present similar proportions (with a diverse number of examples) with few exceptions where the sources differ. The trend to ascribe masculine gender to these nouns has survived in dialects and language of villagers (only the proportions in singular examples have changed, e.g. drużby, ludzie). It seems that we are witnessing more chaos in these forms, especially in syntactic contexts (these are missing especially in the KwAJKLW materials) while formation thereof becomes increasingly difficult for the language of villagers users. We can suppose that the contemporary informants have a set of words which in general are non-masculine (the fundamental example being chtopy, but also $k^{u}$ ośniki, som siady); the other ones are affected by the school-taught norm, hence we should not expect a different use than use in accordance with the general Polish language (e.g. ci ludzie, ci gospodarze). The opposition of masculine- and non-masculine genders is an issue worth observing and studying although a lack of comparative materials from the previous periods is bound to hamper in-depth conclusions.

\section{Summary}

In a monograph dedicated to the dialect spoken in Serpelice, Jan Tokarski wrote at the end of characteristics of noun inflection: "Typically, the final stage of developing noun inflection is presenting it by means of specifically named paradigms. However, 
a prerequisite for these generalised paradigms are analogies of the specific cases that would suggest repartition of the endings in one case affecting repartition in another" (Tokarski 1964, 111). Due to too many various rules determining the endings in the specific groups of nouns, according to J. Tokarski this pattern is useless due to their large number. The situation is similar with creating certain top-down rules within the specific categories in the gender.

Analyses of the chronologically diverse materials of Wielkopolska dialects have indicated differences and similarities in the language spoken in Wielkopolska with the general language norm. There is no denying that the inflection system of a noun is approaching the system of the general Polish language. However, there are still differences which undermine a theory of a grammatical sub-dialectal sub-system but they also prove that a "dialect" is not dying but evolving. What we tend to label as a mistake, is a new grammatical quality from the perspective of a language. In my opinion, the most distinct example is the opposition between masculine and non-masculine, operating in language of villagers according to separate laws than researchers into the general Polish language see it. Another apt example is formation of words for young creatures where this section of the system is evolving as we speak.

The gender category defies attempts at normative ordering thereof; there are many approaches to distinguishing genders and equally numerous deviations from each approach. An oral language is particularly susceptible to gender-related variants where the rules of correctness are somewhat suspended. An oral language is dynamic and this active nature determines the intensity of the specific features of the oral variety of the Polish language - the right form is created once an act of speech is performed (compliance with the general Polish norm does not count - communication is most important). Despite its specificity, the oral variety stays within the limits of more or less flexible norm of the Polish language (in a broader perspective - probably also the general normative frames of Slavic languages) so many of these rules refer also to oral inflection.

Gender variability, transformations within the gender of nouns denoting non-adult creatures and, finally, the opposition between the masculine and non-masculine genders are only a few of the issues related to gender that can be observed and described in dialectal material.

Notably, language of villagers has some unwritten norms ${ }^{43}$ which can be compared with usus. M. Brzezina made an apt comment on the role of usus: "Usus stores obsolete or stylistic variants rejected by the system. Within usus, there is a spontaneous choice between the competing variants, then one of the variants gains in strength while the other one (or the others in the case of three equal variants) decreases in frequency and gradually in range" (Brzezina 1982, 116-117). A similar scenario is adopted for a specific phenomenon within gender in language of villagers. While inflection does not undergo such dramatic changes as does vocabulary, the mechanism of changes is the same. Finally, the old forms are replaced by new ones and dialectal forms with general ones.

${ }^{43}$ I covered this topic in detail in my monograph (Kobus 2015a, 54-60). 
When analysing dialectal material, a researcher should follow two trains of thought: to confront the material with the general language form, to take note of the differences between the two varieties of the Polish language and to appreciate the historical aspect of the forms existing (typically) in dialects. Secondly, in my opinion more important and complicated, a scholar should follow the unwritten norm of the language spoken in a specific village or region in order to observe some language trends (to debunk the myth of the corrupted, incorrect language of villagers). All this, however, is so difficult that neither the inflection of the general or regional Polish language are unambiguous; rather, they are full of exceptions from the adopted paradigm (larger-scale research may even prove that language of villagers is less susceptible to variants with respect to inflection than the general Polish language).

Dialects are a variety of the national language that we would like to attribute to many historical or even pre-historical features. However, this is a variety of language which evolves as do the other varieties of the national language. Therefore, it does not shy from linguistic innovations. Language users will always choose forms sufficient to perform an efficient act of communication. Dialects are at a moment of their developments when the researches try to identify elements typical of a dialect, oblivious to its prevailing structure which stems from the recent communication needs of language of villagers users. There is a reason why we survey language of villagers rather than typical dialects.

A description of the dialectal grammatical system in Wielkopolska is hampered by lack of field research, carried out for many years and targeted. The opinion that the existing materials suffice for grammatical analyses has proven wrong. Contemporary dialectologists should channel at least some of their efforts to regular surveys of systemic issues by adjusting the research methods to the contemporary grammatical forms. It is not enough to ponder the existence or lack of specific forms (typical of a specific dialect). Now, new forms have emerged while the old ones often reveal themselves only in contexts. What is regarded typical of language of villagers may prove to be a marginal phenomenon and vice versa: a general or colloquial phenomenon in language of villagers may assume a different meaning. These phenomena need to be surveyed before we pass a verdict that annihilates dialects.

\section{Bibliography}

AGP, Atlas gwar polskich, vol. 1: K. Dejna, Małopolska, Warszawa 1998; vol. 2: K. Dejna, S. Gala, A. Zdaniukiewicz, Mazowsze, Warszawa 2000; vol. 3: K. Dejna, S. Gala, Śląsk, Warszawa 2001; vol. 4: Dejna K., Wielkopolska, Kaszuby, Warszawa 2002.

AGP-4, K. Dejna, Atlas gwar polskich, vol. 4. Wielkopolska, Kaszuby, Warszawa 2002.

AJKLW, Atlas języka i kultury ludowej Wielkopolski, vol. I-VI, Z. Sobierajski, J. Burszta (eds.), Wrocław 1979-1991; vol. VII-XI, Z. Sobierajski (ed.), Wrocław 1992-2005.

AJKLW-I, Atlas języka i kultury ludowej Wielkopolski, vol. I. Gospodarstwo domowe pożywienie, part 2. Wykazy i komentarze do map 1-115, Z. Sobierajski, J. Burszta (eds.), Wrocław [et al.] 1979. 
AJKLW-II, Atlas języka i kultury ludowej Wielkopolski, vol. 2. Człowiek - Przyroda, part 2. Wykazy i komentarze do map 116-235, Z. Sobierajski, J. Burszta (eds.), Wrocław 1979.

AJKLW-III, Atlas języka i kultury ludowej Wielkopolski, vol. 3. Rolnictwo, part 2. Wykazy i komentarze do map 236-365, Z. Sobierajski, J. Burszta (eds.), Wrocław 1982.

AJKLW-V, Atlas jezzka i kultury ludowej Wielkopolski, vol. 5. Transport, part 2. Wykazy i komentarze do map 436-512, Z. Sobierajski, J. Burszta (eds.), Wrocław 1989.

AJKLW-IX, Atlas języka i kultury ludowej Wielkopolski, vol. 9. Rybotówstwo, part 1. Mapy 702-763, part 2. Wykazy i komentarze do map 702-763, Z. Sobierajski (ed.), Poznań 1996.

Ampel-Rudolf M. (2009), Kategoria rodzaju gramatycznego i semantyczna kategoria istotności poznawczej (żywotności), "Linguistica Copernicana", no. 2 (2), pp. 209-221.

Andrzejczuk A. (2011), Dwoje urodzin to brzmi dziwnie. Norma językowa dotyczaca połaczeń rzeczowników plurale tantum z liczebnikami a jej realizacja $w$ tekstach, "Język Polski" 91, no. 4, pp. 273-283.

Bajerowa I. (1977), Zmiany fleksyjne języka polskiego we współczesnym trzydziestoleciu na tle zmian fleksyjnych języka dawniejszego (XVIII w., XIX w.), "Biuletyn Polskiego Towarzystwa Językoznawczego", issue 35, pp. 13-25.

Bańko M. (2012), Wykłady z polskiej fleksji, Warszawa.

Batko-Tokarz B. (2013), O różnorodnych definicjach słownikowych rzeczowników męskoosobowych, "Poradnik Językowy", issue 10, pp. 71-86.

Bobrowski I. (2005), Rodzaj gramatyczny rzeczownika a jego liczba, "Język Polski" 85, issue 2, pp. 83-89.

Bobrowski I. (2006), Jeszcze o rodzaju gramatycznym rzeczownika, "Polonica" 26-27, pp. 231-254.

Brzezina M. (1977), Twardotematowe feminina gwarowe typu ta łodyg, ta łeb, "Język Polski" 57, issue 5, pp. 347-357.

Brzezina M. (1982), Wariancja rodzaju gramatycznego rzeczowników nieżywotnych $w$ potocznej polszczyźnie, Wrocław.

Brzozowska D. (2005), Kategoria rodzaju we współczesnym języku polskim, "Język Polski" 85, issue 1, pp. 36-42.

Buttler D., Kurkowska H., Satkiewicz H. (1973), Kultura języka polskiego, Warszawa.

Danysz A. (1914), Odrębności stownikarskie kulturalnego języka polskiego w Wielkopolsce w stosunku do kulturalnego języka w Galicji, "Język Polski” 2, issue 8-10, pp. 243-261.

Doroszewski W. (1952), Podstawy gramatyki polskiej, part 1, Warszawa.

EWJ, Encyklopedia wiedzy o języku polskim, S. Urbańczyk (ed.), Warszawa 1978.

Friedelówna T. (1968), Kategoria plurale tantum w języku polskim, Toruń.

Gardzińska J. (1989), Mowa mieszkańców Mogielnicy. Studium socjolingwistyczne, Siedlce.

Górnowicz H. (1967), Dialekt malborski, Gdańsk.

Grad-Mucowa M. (1970), Fleksja rzeczowników w gwarach Mazowsza, Warszawa.

Gramatyka współczesnego języka polskiego. Morfologia, R. Grzegorczykowa, R. Laskowski, H. Wróbel, Warszawa 1998.

Grochola-Szczepanek H. (2010), Korelacja rodzaju gramatycznego i naturalnego $w$ dialektach polskich, "Jezikoslovni zapiski" 16/2, pp. 157-164.

Gruchmanowa M. (1959), Wielkopolskie materiaty gwarowe zebrane przez Adama Tomaszewskiego, "Zeszyty Naukowe Uniwersytetu im. Adama Mickiewicza", no. 23, "Filologia", 
Poznań, pp. 3-10 (reprinted in Gwary w ojczyźnie i na obczyźnie. Studia, Poznań 2003, pp. 32-38).

Gruchmanowa M. (1967), Gwary wielkopolskie, [in:] Kultura ludowa Wielkopolski, J. Burszta (ed.), vol. 3, Poznań, pp. 351-391 (reprinted in: Gwary w ojczyźnie i na obczyźnie. Studia, Poznań 2003, pp. 118-156).

Gruchmanowa M. (2003), Gwary w ojczyźnie i na obczyźnie. Studia, Poznań.

Heinz A. (1974a), Pojęcie i rola wariantu językowego, "Biuletyn PTJ", issue 32, pp. 137-157.

Heinz A. (1974b), Uwagi o wariancji, [in:] Studia indoeuropejskie, J. Kuryłowicz (ed.), Wrocław, pp. 57-63.

Ivić M. (1967), O rodzaju i typach paradygmatycznych polskich rzeczowników, [in:] Studia z filologii polskiej i stowiańskiej 6, Warszawa, pp. 57-61.

Jadacka H. (2005), Kultura języka polskiego. Fleksja, słowotwórstwo, sktadnia, Warszawa.

Karpluk M. (1974), Wahania rodzaju gramatycznego zapożyczeń pod wplywem wyrazów bliskoznacznych (na przykładzie pol. chomąto, dyszel), [in:] Studia indoeuropejskie, J. Kuryłowicz (ed.), Wrocław, pp. 87-90.

Kategorie gramatyczne grup imiennych w języku polskim, R. Laskowski (ed.), Wrocław 1976.

Kąś J. (2015), Ilustrowany leksykon gwary i kultury podhalańskiej, vol. 1: A-B, Bukowina Tatrzańska-Nowy Sącz.

Kępińska A. (2006), Ksztaltowanie się polskiej kategorii męsko- i niemęskoosobowości. Język wobec ptci, Warszawa.

Kleczkowski A. (1920), Dialekt Wilamowic w Zachodniej Galicji. Fonetyka i fleksja, Kraków.

Kobus J. (2007a), Dwie warstwy chronologiczne leksyki z pola tematycznego PRACA w języku mieszkańców wsi wielkopolskich, [in:] "Rozprawy Komisji Językowej ŁTN", vol. 52, pp. 73-82.

Kobus J. (2007b), Rozwarstwienie chronologiczne stownictwa z pola tematycznego PRACA $w$ gwarze Baranówka pod Poznaniem, [in:] Studia nad słownictwem dawnym i współczesnym języków słowiańskich, J. Kamper-Warejko, I. Kaproń-Charzyńska, J. Kulwicka-Kamińska (eds.), Toruń, pp. 301-305.

Kobus J. (2007c), Zróżnicowanie pokoleniowe wsi a problem rozwarstwienia języka jej mieszkańców - leksyka wielkopolska początku XXI wieku, [in:] Gwary dziś, 4. Konteksty dialektologii, J. Sierociuk (ed,), Poznań, pp. 307-314.

Kobus J. (2010), Zmiany leksykalne w języku mieszkańców wielkopolskich wsi wymuszone czynnikami pozajęzykowymi - na przykładzie nazw cepów i ich części, "LingVaria", no. 1 (9), pp. 139-146.

Kobus J. (2014), Opis statyczny czy dynamiczny fleksji gwarowej - rekonesans badawczy, [in:] Badania dialektologiczne. Stan, perspektywy, metodologia, M. Rak and K. Sikora (eds.), Kraków, pp. 81-93.

Kobus J. (2015a), Kierunki dynamika zmian w języku mieszkańców wielkopolskich wsi na przetomie wieków XX i XXI, Poznań

Kobus J. (2015b), Reprezentacja cech systemowych fleksji imiennej w tekstach gwarowych (na przykładzie dopetniacza), [in:] Діалектологічні студіï. 10. Традиції та новаторство, ред. П. Гриценко, Н. Хобзей, Львів, с. 123-140.

Kobus J. (2019), Studia nad fleksja rzeczownika w gwarach wielkopolskich, Poznań.

Kobus J., Gniazdowski T. (2017), O poczuciu przynależności lokalnej na przykładzie języka mieszkańców Modliszewka i okolicy (gm. i pow. Gniezno), [in:] Język w regionie, region 
w języku 2, B. Osowski, J. Kobus, P. Michalska-Górecka, A. Piotrowska-Wojaczyk (eds.), Poznań, pp. 156-157, 158.

Kobus J., Przydatność studenckich materiałów kwestionariuszowych do badań fleksji gwarowej rzeczownika (in press).

Kreja B. (1977), Drobiazgi słowotwórcze, "Język Polski” 57, issue 2, pp. 118-124.

Kucała M. (1976), O rodzaju gramatycznym w języku polskim (Uwagi zwiazane z referatem Z. Saloniego: Kategoria rodzaju we współczesnym języku polskim), [in:] Kategorie gramatyczne grup imiennych grup imiennych $w$ języku polskim. Materiały Konferencji Pracowni Gramatyki Wspótczesnej Polszczyzny Instytutu Języka Polskiego PAN. Zawoja 13-15 XII 1974, R. Laskowski (ed.), Wrocław, pp. 79-87.

Kucała M. (1978), Rodzaj gramatyczny w historii polszczyzny, Wrocław.

Kurek H. (2019), Przemiany fleksji nominalnej w w polszczyźnie przełomu wieków XX i XXI, Kraków.

Kuryłowicz J. (1968), O rozwoju kategorii gramatycznych, Kraków.

Kuryłowicz J. (1931), Polski gen.-acc. plur. męskoosobowy, "Biuletyn Polskiego Towarzystwa Językoznawczego", issue 3, pp. 107-110.

Kuryłowicz J. (1960), W sprawie genezy rodzaju gramatycznego, [in:] Esquissess linguistiques, Wrocław, pp. 151-154.

Kurzowa Z. (1970), Polskie rzeczowniki męskie na -o na tle słowiańskim, Wrocław.

Laskowski R. (1998), Kategorie morfologiczne języka polskiego. Charakterystyka funkcjonalna. 2.2. Rodzaj gramatyczny, [in:] Gramatyka wspótczesnego języka polskiego. Morfologia, R. Grzegorczykowa, R. Laskowski, H. Wróbel (eds.), Warszawa.

Makowska D. (2008), Formy deprecjatywne w Słowniku gramatycznym języka polskiego. Stan obecny i postulaty, "Polonica" 29, pp. 205-226.

Makowska D., Saloni Z. (2009), Polska konstrukcja iść w sołdaty a fleksyjna kategoria deprecjatywności w języku polskim, "Pamiętnik Literacki", issue 1, pp. 145-158.

Małecki M., Nitsch K. (1934), Atlas językowy polskiego Podkarpacia, Kraków.

Mały stownik gwar polskich, J. Wronicz (ed.), Kraków 2010.

Mańczak W. (1956), Ile rodzajów jest w języku polskim?, “Język Polski” 36, issue 2, pp. 116-121.

Mańkowski L. (1901), Jak powstat zwrot tą razą obok tym razem?, "Poradnik Językowy", issue 7, p. 108.

Mazur J. (1978), Gwary okolic Bitgoraja. Część 2. Fleksja, Wrocław.

Gramatyka współczesnego języka polskiego, vol. 2. Morfologia, R. Grzegorczykowa, R. Laskowski, H. Wróbel (eds.), Warszawa 1984, ed. 2 (changed) 1998.

Nagórko A. (1996), Zarys gramatyki polskiej, Warszawa.

Nitsch K. (1914), Odrębności stownikowe Poznania, Krakowa, Warszawy, "Język Polski” 2, issue 8-10, pp. 261-270.

Nowak H. (1970), Gwary chazackie w powiecie rawickim, Poznań.

Nowak H. (1982), Gwary poludniowej Wielkopolski, Poznań.

Nowosad-Bakalarczyk M. (2009), Płeć a rodzaj gramatyczny we wspótczesnej polszczyźnie, Lublin.

NSJP, Nowy słownik języka polskiego, B. Dunaj (ed.), Warszawa 2007.

NSPP, Nowy stownik poprawnej polszczyzny PWN, A. Markowski (ed.), Warszawa 2003. 
Osowski B. (2015), Nazwy istot niedorosłych $w$ osiemnastowiecznych inwentarzach $z$ Wielkopolski, ze szczególnym uwzględnieniem formacji z -ę $i$-ak, "Gwary Dziś", vol. 7, pp. 97-128, DOI 10.14746/gd.2015.7.10.

Pastusiak K. (2004), Fleksja gwar ukraińskich okolic Włodawy, Lublin.

Pelcowa H. (1977), Z zagadnień synkretyzmu fleksyjnego w gwarach Lubelszczyzny. Formy typu te moie stare $\chi$ ar̃upe, 57 , issue 5, pp. 335-342.

Pluta F. (1964), Dialekt głogówecki, cz. 2: Słowotwórstwo, fleksja, teksty gwarowe, Opole.

SRK, Powiedziane po krakowsku. Stownik regionalizmów krakowskich, D. Ochmann, R. Przybylska (eds.), Kraków 2017.

Preyzner M. (1986), Rodzaj w języku polskim, "Prace Filologiczne”, vol. 33, pp. 221-228.

PSWP, Praktyczny słownik wspótczesnej polszczyzny, H. Zgółkowa (ed.), vol. 1-50, Poznań 1994-2005.

Reichan J. (1975), Zmiany we fleksji rzeczowników męskich pierwotnie na spółgłoski wargowe palatalne, Wrocław.

Reczkowa B. (1966), Dwurodzajowość niektórych rzeczowników w gwarach polskich, [in:] Studia językoznawcze poświęcone Profesorowi Doktorowi Stanistawowi Rospondowi, S. Bąk (ed.), Wrocław, pp. 257-261.

Rothstein R.A. (1976), Uwagi o rodzaju gramatycznym i cechach semantycznych wyrazów, "Język Polski” 41, issue 4, pp. 241-253.

Rudnicki S. (2000), Gwara polska wsi Korczunek koło Żytomierza. Fonetyka, fleksja, Warszawa.

Saloni Z. (1976), Kategoria rodzaju we wspótczesnym języku polskim, [in:] Kategorie gramatyczne grup imiennych w języku polskim, R. Laskowski (ed.), Wrocław, pp. 43-78.

Saloni Z. (1988), O tzw. formach nieosobowych [rzeczowników] męskoosobowych we wspótczesnej polszczyźnie, "Biuletyn Polskiego Towarzystwa Językoznawczego", issue 41, pp. 155166.

SDor, Stownik języka polskiego, W. Doroszewski (ed.), vol. 1-11, Warszawa 1958-1969.

Siatkowski J. (1962), Dialekt czeski okolic Kudowy, part 2. Fleksja, stownictwo, teksty, Wrocław.

Sierociuk J. (2003), Założenia metodologiczne badań języka wsi, "Poznańskie Spotkania Językoznawcze", vol. 11, Z. Krążyńska, Z. Zagórski (eds.), Poznań, 131-136.

Sierociuk J. (2007), Język mieszkańców wsi czy gwara. Problem nie tylko teoretyczny, "Prace Filologiczne", vol. 53, pp. 527-534.

SJP PWN, Stownik Języka Polskiego PWN (online version) <https://sjp.pwn.pl (accessed 15.10.2018)>.

SJPSzymczaka, Stownik języka polskiego, M. Szymczak (ed.), vol. 1-3, Warszawa 1988-1989.

Skowrońska D. (2011), Konstrukcje hybrydalne typu stare profesory wiedzieli, młode doktory pytali $w$ języku polskim, "Język Polski" 41, issue 4, pp. 284-293.

Skubalanka T. (1983), O pojęciu variantu fleksyjnego, [in:] Z polskich studiów slawistycznych 6, Warszawa, pp. 369-381.

Skubalanka T. (1989), Warianty fleksyjne w tekstach gwarowych, "Rozprawy Komisji Językowej ŁTN", vol. 34 (1988), pp. 235-242.

Skubalanka T., Książek-Bryłowa W. (1992), Wariantywność polskiej fleksji, Wrocław.

SGP-PAN, Stownik gwar polskich PAN, vol. 1, issues 1-3, M. Karaś (ed.), Wrocław 1977, 1981, 1981; vol. 2, issue 1 (4)-3 (6), J. Reichan, S. Urbańczyk (eds.), Wrocław 1983, 1983, 1986; 
vol. 3, issue 1 (7)-3 (9), J. Reichan, S. Urbańczyk (eds.), Wrocław 1989, 1990, 1991; vol. 4, issue 1 (10)-3 (12), J. Reichan, S. Urbańczyk (eds.), Kraków 1992, 1992, 1993; vol. 5, issue 1 (13)-3 (15), J. Reichan, S. Urbańczyk (eds.), Kraków 1994, 1996, 1998; vol. 6, issue 1 (16)-4 (19), J. Okoniowa, J. Reichan (eds.), Kraków 2001, 2002, 2003, 2004; vol. 7, issue 1 (20)-4 (23), J. Okoniowa, J. Reichan, B. Grabka (eds.), Kraków 2005, 2006, 2007, 2010, vol. 8, issue 1 (24)-4 (27), J. Okoniowa, J. Reichana, B. Grabka (eds.), Kraków 2011, 2012, 2013, 2013, vol. 9, issue 1 (28)-4 (31), B. Grabka, R. Kucharzyk, J. Okoniowa, J. Reichan (eds.), Kraków 2014, 2015, 2016, 2017; vol. 10, issue 1 (32)-2 (33), B. Grabki, R. Kucharzyk (eds.), Kraków 2018, 2019.

Stownik gwary miejskiej Poznania: <http://www.poznan.pl/mim/slownik/words.html?co=word\& word=krawatka $>$ (accessed 18.10.2018).

Sobierajski Z. (1972a), Kwestionariusz do Atlasu języka i kultury ludowej Wielkopolski, part I.: Stownictwo, fonetyka, stowotwórstwo, Poznań (cooperation: M. Gruchmanowa, H. Nowak, Z. Zagórski).

Sobierajski Z. (1972b), Kwestionariusz do Atlasu języka i kultury ludowej Wielkopolski, part 2. Deklinacja, koniugacja, sktadnia, Poznań (cooperation: M. Gruchmanowa, H. Nowak, Z. Zagórski).

Sobierajski Z. (1972c), Kwestionariusz do Atlasu języka i kultury ludowej Wielkopolski, part 3. Etnographica, Poznań (supplemented by T. Wróblewski).

Staszewska Z. (1975), Wahania rodzaju gramatycznego rzeczowników we wspótczesnym języku polskim, "Rozprawy Komisji Językowej ŁTN", vol. 21, pp. 101-116.

Stefańczyk W.T. (2007), Kategoria rodzaju i przypadka polskiego rzeczownika. Próba synchronicznej analizy morfologicznej, Kraków.

Szałkiewicz Ł. (2010), Chamy posły $i$ zuchy doktory - głos $w$ sprawie deprecjatywności, "LingVaria" 5 (1), pp. 219-232.

Szymczak M. (1966), Nazwy stopni pokrewieństwa i powinowactwa rodzinnego $w$ historii $i$ dialektach języka polskiego, Warszawa.

Taszycki W. (1934), Powstanie i rozwój rzeczowników typu cielak (Ustęp z historji narzecza mazowieckiego), "Lud Słowiański. Pismo poświęcone dialektologji i etnografji Słowian", vol. 3, pp. 17-33.

TGPnW, Sobierajski Z. (1990), Teksty gwarowe z pótnocnej Wielkopolski, Wrocław 1990.

TGŚrW, Sobierajski Z., Teksty gwarowe ze środkowej Wielkopolski, Poznań 1995.

TGZchW, Teksty gwarowe z zachodniej Wielkopolski, Wrocław 1985.

Tokarski J. (1973), Fleksja polska, Warszawa.

Tokarski J. (1964), Gwara Serpelic. Fonetyka. Fleksja, Wrocław.

Tokarski J. (1949), Sposoby oznaczania płci w języku a rodzaj gramatyczny, "Poradnik Językowy", issue 4, pp. 8-16.

Tomaszewski A. (1934), Mowa ludu wielkopolskiego. Charakterystyka ogólna z dwoma mapami, Poznań.

Urbańczyk S. (1977), Hierarchia kryteriów poprawności językowej we wspótczesnym języku polskim, [in:] Wariancja normy we wspótczesnych słowiańskich językach literackich, S. Urbańczyk (ed.), Wrocław, pp. 75-83.

USJP, Uniwersalny stownik języka polskiego PWN, S. Dubisz (ed.), Warszawa 2004 (electronic version). 
Wojdak P. (2013), Wielorodzajowość wśród rzeczowników wspótczesnej polszczyzny, Szczecin.

Woliński M. (2001), Rodzajów w polszczyźnie jest osiem, [in:] Nie bez znaczenia... Prace ofiarowane Profesorowi Zygmuntowi Saloniemu. Z okazji jubileuszu 15000 dni pracy naukowej, W. Gruszczyński (ed.), Białystok, pp. 303-305.

Zagórski Z. (1967), Gwary pótnocnej Wielkopolski, Poznań.

Zagórski Z. (1991), O mowie mieszkańców kilkunastu wsi wokół Konina, Wrocław.

Zaron Z. (2004a), Aspekty funkcjonalne polskiej kategorii rodzaju. Charakterystyka fleksyjna, Warszawa.

Zaron Z. (2004b), Rzeczowniki dwurodzajowe - jakie i które?, [in:] Studia z gramatyki i semantyki języka polskiego, A. Moroz, M. Wiśniewski (eds.), Toruń, pp. 161-170.

Zieniukowa J. (1968), Kategoria męskoosobowości w językach słowiańskich, [in:] Językoznawstwo, Prace na VI Międzynarodowy Kongres Slawistów w Pradze 1968, Warszawa, pp. 109-114.

Zieniukowa J. (1974a), Rodzaj męskoosobowy. Rodzaj niemęskoosobowy, [w:] Atlas językowy kaszubszczyzny i dialektów pokrewnych, vol. 11, pod kier. H. Popowskiej-Taborskiej, Wrocław 1974, m. 516-524, s. 87-123.

Zieniukowa J. (1974b), Rodzaj męskoosobowy w dialektach polskich (w świetle opracowań dialektologicznych), "Studia z Filologii Polskiej i Słowiańskiej”, vol. 13-14, pp. 55-63.

Zieniukowa J. (1975), Nominativus pl. rzeczowników męskoosobowych [i] rzeczowników męskożywotnych, [in:] Atlas językowy kaszubszczyzny i dialektów pokrewnych, vol. 12, H. Popowska-Taborska (ed.), Wrocław, entries 560-564, pp. 70-93.

Zieniukowa J. (1981), Rodzaj męskoosobowy we wspótczesnych językach zachodniostowiańskich, Wrocław.

Zierhoffer K. (1956), Nazwy cepów i ich części w Wielkopolsce, "Zeszyty Naukowe UAM. Filologia”, no. 3, pp. 11-23.

Zierhoffer Z. i K. (1987), Nazwy miast Wielkopolski, Poznań. 